\title{
High Strain Rate Tensile Testing of DOP-26 Iridium
}

$\widetilde{\text { UT-BATTELLEE }}$

November 2007

\section{Prepared by}

J. H. Schneibel, C. A. Carmichael, and E. P. George 


\title{
DOCUMENT AVAILABILITY
}

Reports produced after January 1, 1996, are generally available free via the U.S. Department of Energy (DOE) Information Bridge.

Web site http://www.osti.gov/bridge

Reports produced before January 1, 1996, may be purchased by members of the public from the following source.

\author{
National Technical Information Service \\ 5285 Port Royal Road \\ Springfield, VA 22161 \\ Telephone 703-605-6000 (1-800-553-6847) \\ TDD 703-487-4639 \\ Fax 703-605-6900 \\ E-mail info@ntis.gov \\ Web site http://www.ntis.gov/support/ordernowabout.htm
}

Reports are available to DOE employees, DOE contractors, Energy Technology Data Exchange (ETDE) representatives, and International Nuclear Information System (INIS) representatives from the following source.

Office of Scientific and Technical Information

P.O. Box 62

Oak Ridge, TN 37831

Telephone 865-576-8401

Fax 865-576-5728

E-mail reports@osti.gov

Web site http://www.osti.gov/contact.html

This report was prepared as an account of work sponsored by an agency of the United States Government. Neither the United States Government nor any agency thereof, nor any of their employees, makes any warranty, express or implied, or assumes any legal liability or responsibility for the accuracy, completeness, or usefulness of any information, apparatus, product, or process disclosed, or represents that its use would not infringe privately owned rights. Reference herein to any specific commercial product, process, or service by trade name, trademark, manufacturer, or otherwise, does not necessarily constitute or imply its endorsement, recommendation, or favoring by the United States Government or any agency thereof. The views and opinions of authors expressed herein do not necessarily state or reflect those of the United States Government or any agency thereof. 
Radioisotope Power Systems Program

\title{
HIGH STRAIN RATE TENSILE TESTING OF DOP-26 IRIDIUM
}

\author{
J. H. Schneibel, C. A. Carmichael, and E. P. George
}

Date Published: November 2007

\author{
Prepared by \\ OAK RIDGE NATIONAL LABORATORY \\ Oak Ridge, Tennessee 37831-6283 \\ managed by \\ UT-BATTELLE, LLC \\ for the \\ U.S. DEPARTMENT OF ENERGY \\ under contract DE-AC05-00OR22725
}





\section{CONTENTS}

\section{Page}

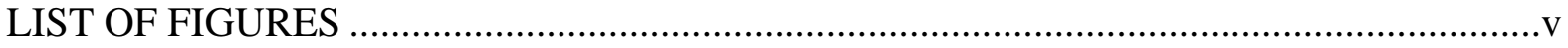

LIST OF TABLES ................................................................................................ vii

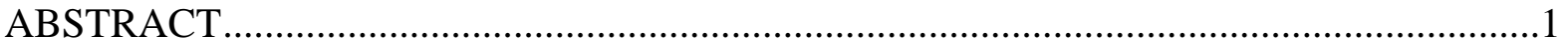

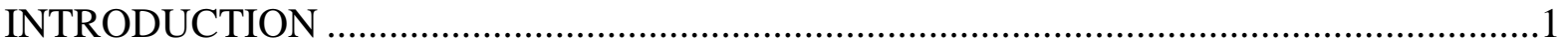

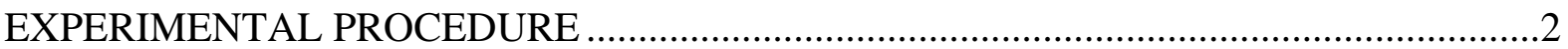

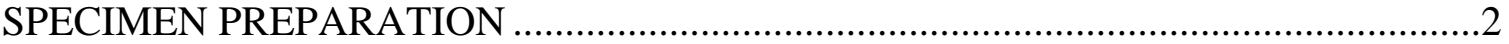

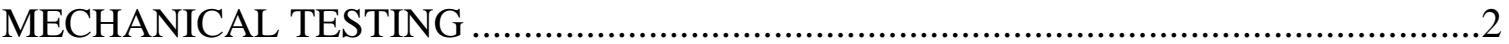

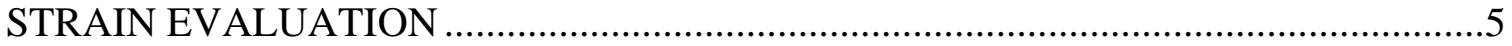

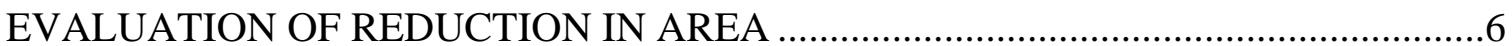

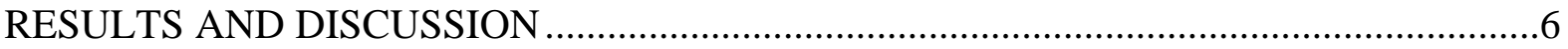

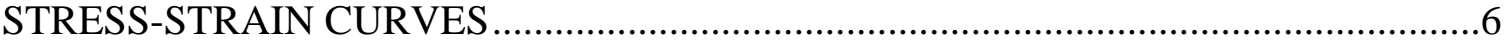

YIELD STRESS, ULTIMATE TENSILE STRESS, FRACTURE

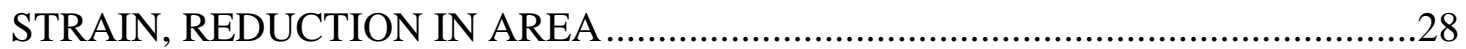

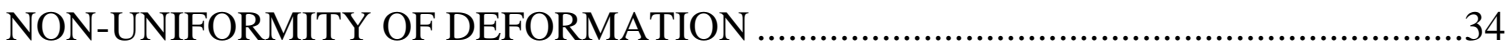

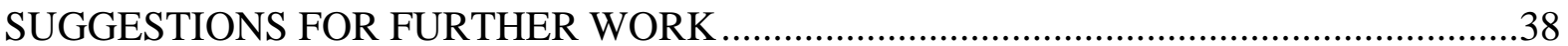

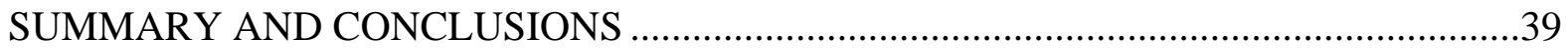

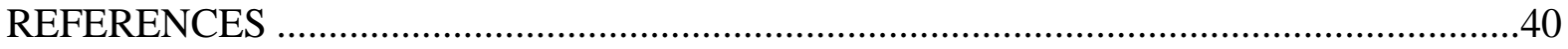

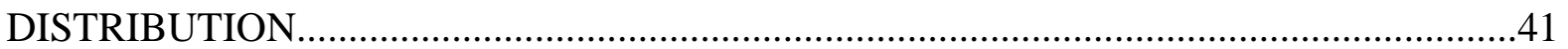




\section{LIST OF FIGURES}

Figure

Page

1 Machining instructions for tensile test specimens .4

2 Stress vs. crosshead strain

3 Stress-strain curves at $10^{-3} \mathrm{~s}^{-1}$ and $25^{\circ} \mathrm{C}$, longitudinal specimen orientation,

a) full curves, (b) yield region...

4 Stress-strain curves at $10^{-3} \mathrm{~s}^{-1}$ and $600^{\circ} \mathrm{C}$, longitudinal specimen orientation,

(a) full curves, (b) yield region.

5 Stress-strain curves at $10^{-3} \mathrm{~s}^{-1}$ and $750^{\circ} \mathrm{C}$, longitudinal specimen orientation,

(a) full curves, (b) yield region2

6 Stress-strain curves at $10^{-3} \mathrm{~s}^{-1}$ and $900^{\circ} \mathrm{C}$, longitudinal specimen orientation,

(a) full curves, (b) yield region .................................................................

7 Stress-strain curves at $10^{-3} \mathrm{~s}^{-1}$ and $1090^{\circ} \mathrm{C}$, longitudinal specimen orientation,

(a) full curves, (b) yield region.

8 Stress-strain curves at $10 \mathrm{~s}^{-1}$ and $25^{\circ} \mathrm{C}$, longitudinal specimen orientation,

(a) full curves, (b) yield region

9 Stress-strain curves at $10 \mathrm{~s}^{-1}$ and $600^{\circ} \mathrm{C}$, longitudinal specimen orientation,

(a) full curves, (b) yield region .16

10 Stress-strain curves at $10 \mathrm{~s}^{-1}$ and $750^{\circ} \mathrm{C}$, longitudinal specimen orientation,

(a) full curves, (b) yield region.

11 Stress-strain curves at $10 \mathrm{~s}^{-1}$ and $900^{\circ} \mathrm{C}$, longitudinal specimen orientation,

(a) full curves, (b) yield region

12 Stress-strain curves at $10 \mathrm{~s}^{-1}$ and $1090^{\circ} \mathrm{C}$, longitudinal specimen orientation, (a) full curves, (b) yield region.

13 Stress-strain curves at $50 \mathrm{~s}^{-1}$ and $25^{\circ} \mathrm{C}$, longitudinal specimen orientation

14 Stress-strain curves at $50 \mathrm{~s}^{-1}$ and $600^{\circ} \mathrm{C}$, longitudinal specimen orientation 
15 Stress-strain curves at $50 \mathrm{~s}^{-1}$ and $750^{\circ} \mathrm{C}$, longitudinal specimen

orientation

16 Stress-strain curves at $50 \mathrm{~s}^{-1}$ and $900^{\circ} \mathrm{C}$, longitudinal specimen

orientation

17 Stress-strain curves at $50 \mathrm{~s}^{-1}$ and $1090^{\circ} \mathrm{C}$, longitudinal specimen

orientation

18 Stress-strain curves at $10^{-3} \mathrm{~s}^{-1}$ and $750^{\circ} \mathrm{C}$, transverse specimen orientation,

(a) full curves, (b) yield region

19 Stress-strain curves at $10^{-3} \mathrm{~s}^{-1}$ and $1090^{\circ} \mathrm{C}$, transverse specimen orientation,

(a) full curves, (b) yield region

20 Stress-strain curves at $10 \mathrm{~s}^{-1}$ and $750^{\circ} \mathrm{C}$, transverse specimen orientation,

(a) full curves, (b) yield region

21 Stress-strain curves at $10 \mathrm{~s}^{-1}$ and $1090^{\circ} \mathrm{C}$, transverse specimen orientation,

(a) full curves, (b) yield region

22 Stress-strain curves at $50 \mathrm{~s}^{-1}$ and $750^{\circ} \mathrm{C}$, transverse specimen orientation

23 Stress-strain curves at $50 \mathrm{~s}^{-1}$ and $1090^{\circ} \mathrm{C}$, transverse specimen

orientation

24 Plot of yield stress vs. temperature for longitudinal and transverse orientation at different strain rates

25 Plot of ultimate tensile stress vs. temperature for longitudinal and transverse orientations at different strain rates.

26 Plot of fracture strain vs. temperature for longitudinal and transverse orientations at different strain rates.

27 Plot of reduction in area vs. temperature for longitudinal and transverse orientations at different strain rates.

28 Local indent fracture strains for longitudinal DOP 26 specimens tested at $1 \times 10^{-3} \mathrm{~s}^{-1}$

29 Local indent fracture strains for longitudinal DOP specimens tested at 50 $\mathrm{s}^{-1}$ 


\section{LIST OF TABLES}

Table

Page

I Fracture strains and slopes of elastic lines for longitudinal DOP-26

specimens

II $\quad$ Fracture strains and slopes of elastic lines for traverse DOP-26

specimens

III Strain correction factors for calculating the plastic strain from curves of

stress vs. crosshead strain

IV Longitudinal DOP-26 iridium (Sheet identification K3-14) at different strain rates and temperatures (T): $0.2 \%$ yield stress (YS), ultimate tensile stress (UTS), fracture strain (elongation to fracture), and reduction in area $(\mathrm{RA})$

V Transverse DOP-26 iridium (blank identifications GR9-1 \#4; GR9-2 \#1, \#4, \#5. \#6, \#7) at different strain rates and temperatures (T): $0.2 \%$ yield stress (YS), ultimate tensile stress (UTS), fracture strain (elongation to fracture), and reduction in area $(\mathrm{RA})$

VI Averaged mechanical properties for longitudinal and transverse DOP-26 iridium alloy

VII Heestand et al. tensile data [12] for stress-relieved $\left(1 \mathrm{~h} / 1025^{\circ} \mathrm{C}\right)$ DOP-26 iridium alloy (B2-7 sheet) tested at $925^{\circ} \mathrm{C}$ and $6.7 \times 10^{-1} \mathrm{~s}^{-1}$

VIII Local strains determined from the change in spacing of indents 1 through 7

for longitudinal DOP-26 specimens.

IX Local strains determined from the change in spacing of indents 1 through 7

for transverse DOP-26 specimens 


\title{
HIGH STRAIN RATE TENSILE TESTING OF DOP-26 IRIDIUM*
}

\author{
J. H. Schneibel, C. A. Carmichael and E. P. George
}

\begin{abstract}
The iridium alloy DOP-26 was developed through the Radioisotope Power Systems Program in the Office of Nuclear Energy of the Department of Energy. It is used for clad vent set cups containing radioactive fuel in radioisotope thermoelectric generator (RTG) heat sources which provide electric power for spacecraft. This report describes mechanical testing results for DOP-26. Specimens were given a vacuum recrystallization anneal of 1 hour at $1375^{\circ} \mathrm{C}$ and tested in tension in orientations parallel and perpendicular to the rolling direction of the sheet from which they were fabricated. The tests were performed at temperatures ranging from room temperature to $1090^{\circ} \mathrm{C}$ and strain rates ranging from $1 \times 10^{-3}$ to $50 \mathrm{~s}^{-1}$. Room temperature testing was performed in air, while testing at elevated temperatures was performed in a vacuum better than $1 \times 10^{-4}$ Torr. The yield stress (YS) and the ultimate tensile stress (UTS) decreased with increasing temperature and increased with increasing strain rate. Between 600 and $1090^{\circ} \mathrm{C}$, the ductility showed a slight increase with increasing temperature. Within the scatter of the data, the ductility did not depend on the strain rate. The reduction in area (RA), on the other hand, decreased with increasing strain rate. The YS and UTS values did not differ significantly for the longitudinal and transverse specimens. The ductility and RA values of the transverse specimens were marginally lower than those of the longitudinal specimens.
\end{abstract}

\section{INTRODUCTION}

Iridium exhibits a unique combination of a high melting point $\left(2443^{\circ} \mathrm{C}\right)$, good oxidation resistance, and excellent high-temperature strength [1]. In a review of 25 years of research on iridium as a structural material, George and Liu [1] showed that its mechanical properties can be significantly improved by macroalloying (typically $>1 \mathrm{wt} \%$ ) and microalloying (typically $<1 \mathrm{wt} \%$ ). Macroalloying with $\mathrm{W}$ or $\mathrm{Hf}$ increases the yield strength and the recrystallization temperature [1-6]. Microalloying with Th raises the recrystallization temperature, impedes grain growth, and increases the tensile impact ductility by strengthening the grain boundaries [1,2-5]. The beneficial effect of Th is due to grain boundary segregation [7] and the formation

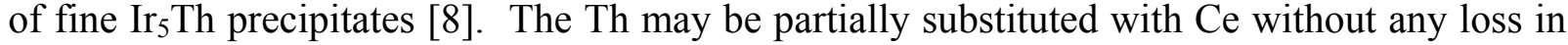
the mechanical properties $[9,10]$. In fact, newly developed alloys containing Th and Ce exhibit improved high-temperature impact ductility and weldability [1].

\footnotetext{
*Research sponsored by the Office of Radioisotope Power Systems at the Oak Ridge National Laboratory, managed by UT-Battelle, LLC for the U.S. Department of Energy under contract number DE-AC05-00OR22725
} 
Iridium exhibits the face-centered cubic crystal structure. Unlike other elements with this crystal structure, its mechanical properties are strain rate sensitive. The mechanical behavior of iridium thus resembles that of body-centered cubic metals [1]. As a result of the strain rate sensitivity, the ductility of iridium decreases with increasing strain rate. For example, whereas the elongation to fracture at a temperature of $800^{\circ} \mathrm{C}$ and a strain rate of $\sim 10^{-3} \mathrm{~s}^{-1}$ reaches $\sim 55 \%$, an increase in the strain rate by six orders of magnitude to $\sim 10^{3} \mathrm{~s}^{-1}$ reduces this value to $\sim 15 \%$ [10]. In critical applications of iridium it is therefore important to characterize the strain rate dependence of the mechanical properties.

An important application of iridium is radioisotope thermoelectric generators (RTGs) for space power applications [11]. In RTGs, the iridium alloy DOP-26 is used as cladding for ${ }^{238} \mathrm{PuO}_{2}$ fuel. DOP-26 was developed at the Oak Ridge National Laboratory [1-5]. It is an Ir- $0.3 \mathrm{wt} \% \mathrm{~W}$ alloy containing $60 \mathrm{wppm}$ Th to improve the high temperature impact ductility. To date, most of the mechanical property testing of DOP-26 consisted of tensile tests at $\sim 10^{-3} \mathrm{~s}^{-1}$ and impact tests at $\sim 10^{3} \mathrm{~s}^{-1}$. In order to add intermediate strain rates to this mechanical properties database, the present work measures the strength and ductility of DOP-26 at temperatures ranging from room temperature to $1090^{\circ} \mathrm{C}$ and strain rates ranging from $10^{-3} \mathrm{~s}^{-1}$ to $50 \mathrm{~s}^{-1}$. Tests were performed parallel and perpendicular to the sheet rolling direction in order to assess the effect of the orientation on the mechanical properties.

\section{EXPERIMENTAL PROCEDURE}

\section{SPECIMEN PREPARATION}

Tensile specimens were electro-discharge machined from stress-relieved DOP-26 iridium sheet with a thickness between 0.6 and $0.7 \mathrm{~mm}$, followed by grinding to the final dimensions (Fig. 1). The edges of the gage lengths and fillet radii of the specimens were polished with 320 and 600 grit $\mathrm{SiC}$ paper. After dimensional inspection, the specimens were cleaned for 30 minutes in a solution of 3 parts $\mathrm{HCl}$ and 1 part $\mathrm{HNO}_{3}$ by volume, plus 15 vol\% $\mathrm{HF}$ (conc.), followed by rinsing in distilled water and ethanol. The cleaned specimens were annealed for 1 hour at $1375^{\circ} \mathrm{C}$ in a vacuum better than $1 \times 10^{-4}$ Torr. The gage length of each specimen was marked with a row of seven 1000-g microhardnesss impressions spaced at 1.5-mm intervals.

\section{MECHANICAL TESTING}

The tensile tests were carried out in a servohydraulic 1321 Instron testing machine equipped with a turbo-pumped vacuum system and a radio frequency (RF) heater for heating up a tantalum susceptor supported by an alumina tube. Prior to testing, each specimen was inserted into mating molybdenum alloy (TZM) grips that supported it on the $5 \mathrm{~mm}$ radius shoulders. Room temperature tests were performed in air. Tests above room temperature were performed in a vacuum better than $1 \times 10^{-4}$ Torr. The specimen temperature was measured with two Pt$\mathrm{Pt} / \mathrm{Rh}$ type $\mathrm{S}$ thermocouples that were placed on the specimen gage section and wrapped with $0.4 \mathrm{~mm}$ diameter Pt wire. The distance between the two thermocouples was typically $5 \mathrm{~mm}$. 
During testing, the temperature was held within $\pm 10^{\circ} \mathrm{C}$ of the target value. The load cell was calibrated with an accuracy of $\pm 1 \%$ of its reading. The cross-sectional area of the specimens was determined from the specimen thickness and the width W2 (Fig. 1) with an accuracy of $1 \%$, resulting in an overall accuracy of the stress measurement of $\pm 2 \%$.

Because of the small size of the specimens, the load signal obtained at low strain rates $\left(1 \times 10^{-3} \mathrm{~s}^{-1}\right)$ exhibited noise and was therefore smoothed. In a few of the slow tests at high temperatures, the reading of the load cell at zero load drifted during the test. If the drift corresponded to more than about $10 \mathrm{MPa}$ at the completion of the test, the stress data were adjusted by assuming that the reading of the load cell at zero load drifted linearly with time.

For the tests carried out at $10^{-3}$ and $10 \mathrm{~s}^{-1}$, an elastic load-displacement line (which was governed by the compliances of the testing system and the specimen) was obtained by fitting a straight line to the region of maximum slope below the yield point (Fig. 2). It should be pointed out that this elastic line was not truly elastic - upon loading, plastic seating of the specimens occurred, presumably due to an imperfect mating between the specimen shoulders and the grips. This resulted in specimen-to-specimen variations in the slope of the "elastic" line by up to a factor of 2. The curve ID\#43 in Fig. 3 provides an example of this effect: this specimen was preloaded to approximately $50 \mathrm{MPa}$, unloaded, and then tested. It is readily seen that the elastic slope below $50 \mathrm{MPa}$ is higher than that above $50 \mathrm{MPa}$. Presumably, the reason for this is the elimination of any plastic deformation below $50 \mathrm{MPa}$ because of the preloading. In the following, we will use the term "elastic line" even though, strictly speaking, it is not an elastic line. At a strain rate of $50 \mathrm{~s}^{-1}$, the elastic load-displacement line could not be determined since the data acquisition rate was limited to $5 \mathrm{kHz}$ corresponding to a point-topoint spacing of $1 \%$ strain. Therefore, an average value of the elastic line obtained from the $10^{-3}$ and $10 \mathrm{~s}^{-1}$ data was used instead. At $50 \mathrm{~s}^{-1}$ no attempt was made to determine the yield stress.

At 10 and $50 \mathrm{~s}^{-1}$, oscillations of the stress were usually observed during testing. These oscillations ("ringing") were associated with the load frame and the upper load train which was attached to the load cell. Their amplitude was significantly reduced by reducing the mass of the upper load train from an initial value of $750 \mathrm{~g}$ to approximately $300 \mathrm{~g}$. However, the ringing could not be entirely eliminated. At $10 \mathrm{~s}^{-1}$, approximately 5 oscillations were observed during tests performed at $600^{\circ} \mathrm{C}$ and above. Stress averaging was carried out near the maximum stress in order to determine the ultimate tensile stress (UTS) more precisely. At $50 \mathrm{~s}^{-1}$, the tests took place in less than one ringing period. This resulted in differences in the shape of the stress-strain curves for nominally identical testing conditions, resulting in additional scatter. 


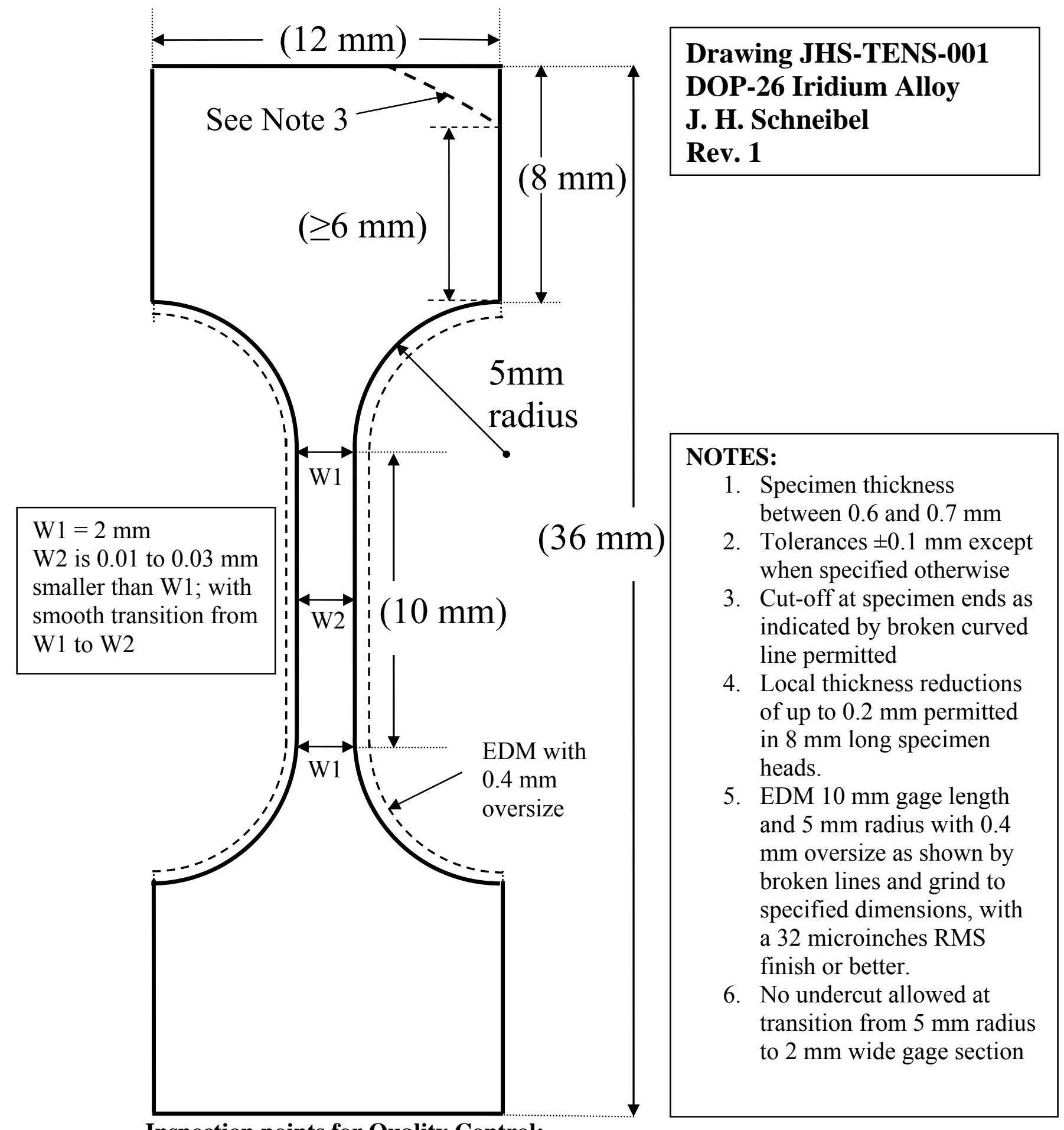

Inspection points for Quality Control:

1. Specimen width W1 (top), W1 (bottom), and W2

2. Specimen thickness in center of gage length

3. Verification of the $5 \mathrm{~mm}$ radii for the four shoulders

Fig. 1. Machining instructions for tensile test specimens. 


\section{STRAIN EVALUATION}

The low yield stress and small size of the specimens precluded the attachment of extensometers to the specimen gage. Realistic stress-strain curves were therefore obtained from the load vs. crosshead extension by a correction procedure based on the spacing of the microhardness indents after testing. First, uncorrected specimen strains, i.e., "crosshead strains," were obtained by dividing the crosshead extension by the nominal gage length, 10 $\mathrm{mm}$. An elastic line was drawn through the maximum slope portion of the test curve below the yield point, and a line with the same slope through the point of fracture as shown in Fig. 2. The "crosshead fracture strain" was defined as the horizontal separation between those two lines. The "crosshead plastic strain" for each point on the test curve in Fig. 2 was defined as the horizontal distance between the elastic line and that point. In the case of sudden fracture at the UTS, the elastic line at fracture was placed through the point at which the UTS was observed. In the case of gradual fracture, the elastic line was placed through a point on the decreasing part of the stress-strain curve corresponding to 0.8 times the UTS. The experimental variations in the slope of the elastic lines resulted in an uncertainty in the crosshead fracture strains on the order of $\pm 1 \%$ strain, but in some cases an uncertainty of up to $\pm 2 \%$ strain was encountered.

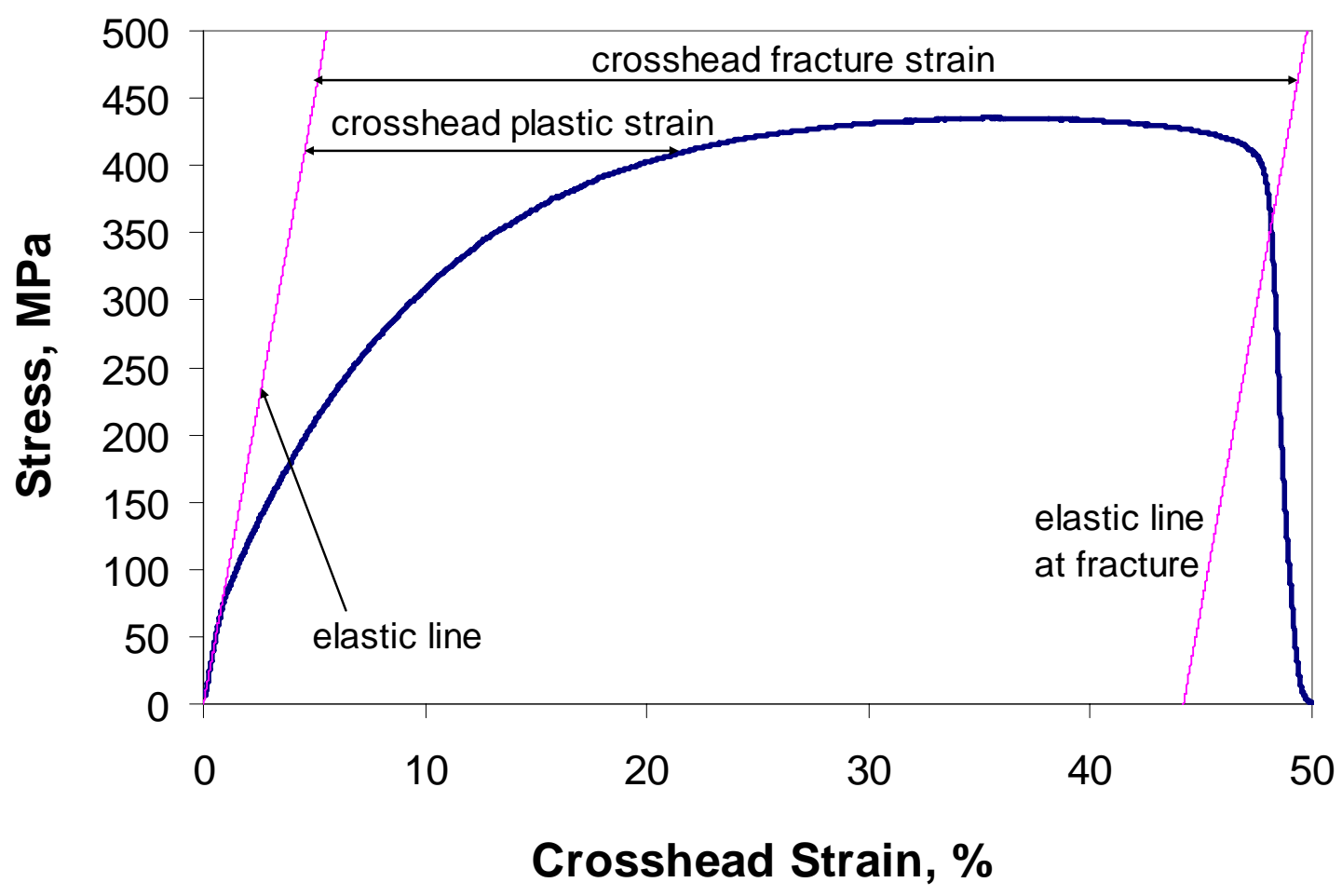

Fig. 2. Stress vs. crosshead strain.

Deformation of the specimens did not occur exclusively in the $10 \mathrm{~mm}$ gage length. During testing the deformation propagated to the specimen shoulders. This resulted in errors in the crosshead fracture strain (which was calculated assuming a $10 \mathrm{~mm}$ gage length). In order to 
obtain a realistic measure of the specimen plastic strain, corrections using the "indent fracture strain" were made. The indent fracture strain is the average of the local strains calculated from the increase in the indent-indent spacing after testing a specimen. The strain corresponding to the two indents between which fracture occurred was not evaluated, i.e., only 5 spacings were typically evaluated. Occasionally, an indent could not be found after testing, and then only 4 spacings were available for the evaluation of the fracture strain.

The indent fracture strain was not used directly to correct the crosshead plastic strain. This is because the scatter in the indent fracture strains was significantly higher than that in the crosshead fracture strains. The following procedure was adopted to calculate the specimen plastic strain (Fig. 2): For each specimen, the ratio of the indent fracture strain and the crosshead fracture strain was evaluated. For each test temperature, the average of these ratios was calculated. The "specimen plastic strain" was calculated by multiplying the crosshead plastic strain with the strain correction factor pertaining to the test temperature. The final plots of (engineering) stress vs. (engineering) strain were obtained from curves of the stress vs. the crosshead strain such as that in Fig. 2 by replacing the crosshead plastic strain with the specimen plastic strain. The fracture strains (also called ductility or elongation to fracture) were obtained by multiplying the crosshead fracture strains with the corresponding strain correction factors.

\section{EVALUATION OF REDUCTION IN AREA}

The reduction in area (RA) was determined from the initial cross section, $\mathrm{A}_{\mathrm{i}}$, and the fracture area, $\mathrm{A}_{\mathrm{f}}$, of the tested specimens using the relationship:

$$
\mathrm{RA}=100 \% \times\left(\mathrm{A}_{\mathrm{i}}-\mathrm{A}_{\mathrm{f}}\right) / \mathrm{A}_{\mathrm{i}}
$$

$A_{i}$ was obtained by multiplying the specimen thickness with the specimen width W2 (Fig. 2). The projected fracture surface area $A_{f}$ of each specimen was evaluated from scanning electron microscope micrographs using a 500 lines per inch calibration standard. $A_{f}$ could be determined with an accuracy of $3 \%$. Only one of the two fracture surfaces of each specimen was examined.

\section{RESULTS AND DISCUSSION}

\section{STRESS-STRAIN CURVES}

Tables I and II tabulate the slopes of the elastic lines, the crosshead fracture strains, and the indent fracture strains for the longitudinal and transverse tests. The ratios of the crosshead and indent fracture strains were averaged to determine the strain correction factor for each temperature (see Table III). Table III shows that the strain correction factor for room temperature is much smaller than the corresponding values at $600^{\circ} \mathrm{C}$ and above. The reason for this is the extremely high work hardening capacity of DOP-26 at room temperature - the pronounced hardening of the gage section during testing causes significant plastic deformation 
in the shoulder and head sections of the specimen, and a concomitant increase in the effective gage length.

The fracture strains were determined by multiplying the crosshead fracture strains with the corresponding correction factor (Table III). The crosshead plastic strains were multiplied with the appropriate correction factor to obtain the final stress-strain curves. These curves are plotted in Figs. 3-23. 
Table I. Fracture strains and slopes of elastic lines for longitudinal DOP-26 specimens

\begin{tabular}{|c|c|c|c|c|c|}
\hline ID\# & $\begin{array}{l}\text { Strain } \\
\text { rate, } \mathrm{s}^{-1}\end{array}$ & $\mathrm{~T},{ }^{\circ} \mathrm{C}$ & $\begin{array}{l}\text { Slope of elastic line, } \\
\mathrm{MPa} / \% \text { crosshead strain }\end{array}$ & $\begin{array}{l}\text { Crosshead } \\
\text { fracture strain, } \%\end{array}$ & $\begin{array}{c}\text { Indent fracture } \\
\text { strain, } \%\end{array}$ \\
\hline 1 & $1 \times 10^{-3}$ & 25 & 217 & 14.3 & 8.6 \\
\hline 32 & $1 \times 10^{-3}$ & 25 & 183 & 14.4 & 9.0 \\
\hline 43 & $1 \times 10^{-3}$ & 25 & 202 & 16.9 & 10.0 \\
\hline 2 & $1 \times 10^{-3}$ & 600 & 90 & 44.2 & 34.7 \\
\hline 19 & $1 \times 10^{-3}$ & 600 & 248 & 38.8 & 25.8 \\
\hline 33 & $1 \times 10^{-3}$ & 600 & 112 & 41.1 & 28.5 \\
\hline 20 & $1 \times 10^{-3}$ & 750 & 87 & 45.0 & 30.8 \\
\hline 35 & $1 \times 10^{-3}$ & 750 & 110 & 43.6 & 32.4 \\
\hline 4 & $1 \times 10^{-3}$ & 900 & 97 & 47.6 & 33.5 \\
\hline 21 & $1 \times 10^{-3}$ & 900 & 113 & 47.2 & 34.8 \\
\hline 36 & $1 \times 10^{-3}$ & 900 & 92 & 49.8 & 38.8 \\
\hline 5 & $1 \times 10^{-3}$ & 1090 & 227 & 54.0 & 39.1 \\
\hline 37 & $1 \times 10^{-3}$ & 1090 & 147 & 52.7 & 38.2 \\
\hline 45 & $1 \times 10^{-3}$ & 1090 & 90 & 52.6 & 40.8 \\
\hline 6 & 10 & 25 & 148 & 15.7 & 10.1 \\
\hline 23 & 10 & 25 & 204 & 16.2 & 9.4 \\
\hline 38 & 10 & 25 & 168 & 18.4 & 11.4 \\
\hline 7 & 10 & 600 & 99 & 41.8 & 33.1 \\
\hline 24 & 10 & 600 & 116 & 43.6 & 32.5 \\
\hline 39 & 10 & 600 & 216 & 45.3 & 34.6 \\
\hline 8 & 10 & 750 & 108 & 46.9 & 38.3 \\
\hline 25 & 10 & 750 & 182 & 40.7 & 27.3 \\
\hline 40 & 10 & 750 & 142 & 45.9 & 35.8 \\
\hline 9 & 10 & 900 & 102 & 42.2 & 30.5 \\
\hline 26 & 10 & 900 & 146 & 33.7 & 25.7 \\
\hline 41 & 10 & 900 & 171 & 42.2 & 32.2 \\
\hline 11 & 10 & 1090 & 177 & 50.0 & 35.4 \\
\hline 27 & 10 & 1090 & 215 & 49.9 & 40.1 \\
\hline 42 & 10 & 1090 & 118 & 45.7 & 35.5 \\
\hline 12 & 50 & 25 & 150 & 15.5 & 9.5 \\
\hline 28 & 50 & 25 & 150 & 15.9 & 10.3 \\
\hline 44 & 50 & 25 & 150 & 14.3 & 9.4 \\
\hline 13 & 50 & 600 & 150 & 46.0 & 33.4 \\
\hline 29 & 50 & 600 & 150 & 47.3 & 33.1 \\
\hline 50 & 50 & 600 & 150 & 44.9 & 34.5 \\
\hline 14 & 50 & 750 & 150 & 52.5 & 38.2 \\
\hline 30 & 50 & 750 & 150 & 49.2 & 34.4 \\
\hline 48 & 50 & 750 & 150 & 49.6 & 38.6 \\
\hline 15 & 50 & 900 & 150 & 44.5 & 30.5 \\
\hline 17 & 50 & 900 & 150 & 43.6 & 32.1 \\
\hline 47 & 50 & 900 & 150 & 44.5 & 33.6 \\
\hline 16 & 50 & 1090 & 150 & 60.0 & 46.1 \\
\hline 46 & 50 & 1090 & 150 & 47.9 & 34.8 \\
\hline 49 & 50 & 1090 & 150 & 46.8 & 31.1 \\
\hline
\end{tabular}


Table II. Fracture strains and slopes of elastic lines for transverse DOP-26 specimens

\begin{tabular}{cccccc}
\hline \hline ID\# & $\begin{array}{l}\text { Strain } \\
\text { rate, } \mathrm{s}^{-1}\end{array}$ & $\mathrm{~T},{ }^{\circ} \mathrm{C}$ & $\begin{array}{l}\text { Slope of elastic line, } \\
\text { MPa/\% crosshead strain }\end{array}$ & $\begin{array}{l}\text { Crosshead } \\
\text { fracture strain, \% }\end{array}$ & $\begin{array}{l}\text { Indent fracture } \\
\text { strain, \% }\end{array}$ \\
\hline $51 \mathrm{~T}$ & $1 \times 10^{-3}$ & 750 & 92 & 43.3 & 33.4 \\
$52 \mathrm{~T}$ & $1 \times 10^{-3}$ & 750 & 155 & 40.0 & 29.5 \\
$66 \mathrm{~T}$ & $1 \times 10^{-3}$ & 750 & 145 & 40.0 & 27.3 \\
$53 \mathrm{~T}$ & $1 \times 10^{-3}$ & 1090 & 152 & 46.1 & 36.3 \\
$54 \mathrm{~T}$ & $1 \times 10^{-3}$ & 1090 & 107 & 45.7 & 30.1 \\
$68 \mathrm{~T}$ & $1 \times 10^{-3}$ & 1090 & 91 & 46.7 & 35.5 \\
$55 \mathrm{~T}$ & 10 & 750 & 176 & 42.8 & 31.2 \\
$62 \mathrm{~T}$ & 10 & 750 & 141 & 43.6 & 36.0 \\
$64 \mathrm{~T}$ & 10 & 750 & 142 & 45.9 & 33.8 \\
$58 \mathrm{~T}$ & 10 & 1090 & 196 & 46.6 & 38.3 \\
$65 \mathrm{~T}$ & 10 & 1090 & 101 & 38.9 & 27.4 \\
$67 \mathrm{~T}$ & 10 & 1090 & 133 & 47.0 & 38.6 \\
$56 \mathrm{~T}$ & 50 & 750 & 150 & 45.7 & 35.5 \\
$59 \mathrm{~T}$ & 50 & 750 & 150 & 46.8 & 38.1 \\
$61 \mathrm{~T}$ & 50 & 750 & 150 & 42.7 & 33.4 \\
$57 \mathrm{~T}$ & 50 & 1090 & 150 & 52.1 & 41.1 \\
$60 \mathrm{~T}$ & 50 & 1090 & 150 & 46.1 & 34.4 \\
$63 \mathrm{~T}$ & 50 & 1090 & 150 & 49.7 & 39.7 \\
\hline \hline
\end{tabular}

Table III. Strain correction factors for calculating the plastic strain from curves of stress vs. crosshead strain

\begin{tabular}{|c|c|c|}
\hline $\mathrm{T},{ }^{\circ} \mathrm{C}$ & $\begin{array}{l}\text { Strain correction factor, } \\
\text { longitudinal specimens }\end{array}$ & $\begin{array}{l}\text { Strain correction factor, } \\
\text { transverse specimens }\end{array}$ \\
\hline 25 & 0.620 & \\
\hline 600 & 0.738 & \\
\hline 750 & 0.737 & 0.763 \\
\hline 900 & 0.738 & \\
\hline 1090 & 0.741 & 0.767 \\
\hline
\end{tabular}



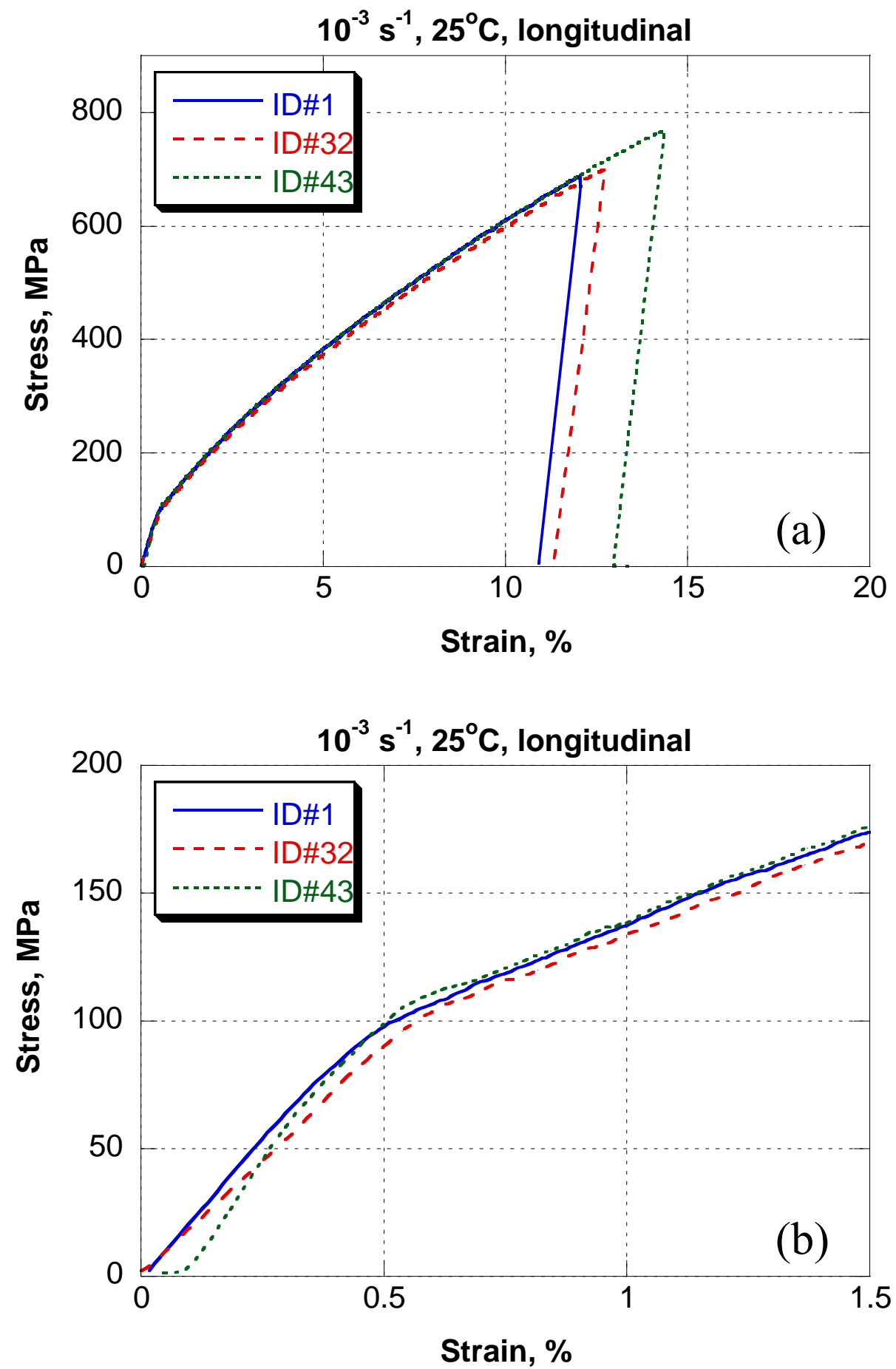

Fig. 3. Stress-strain curves at $10^{-3} \mathrm{~s}^{-1}$ and $25^{\circ} \mathrm{C}$, longitudinal specimen orientation, (a) full curves, (b) yield region. 

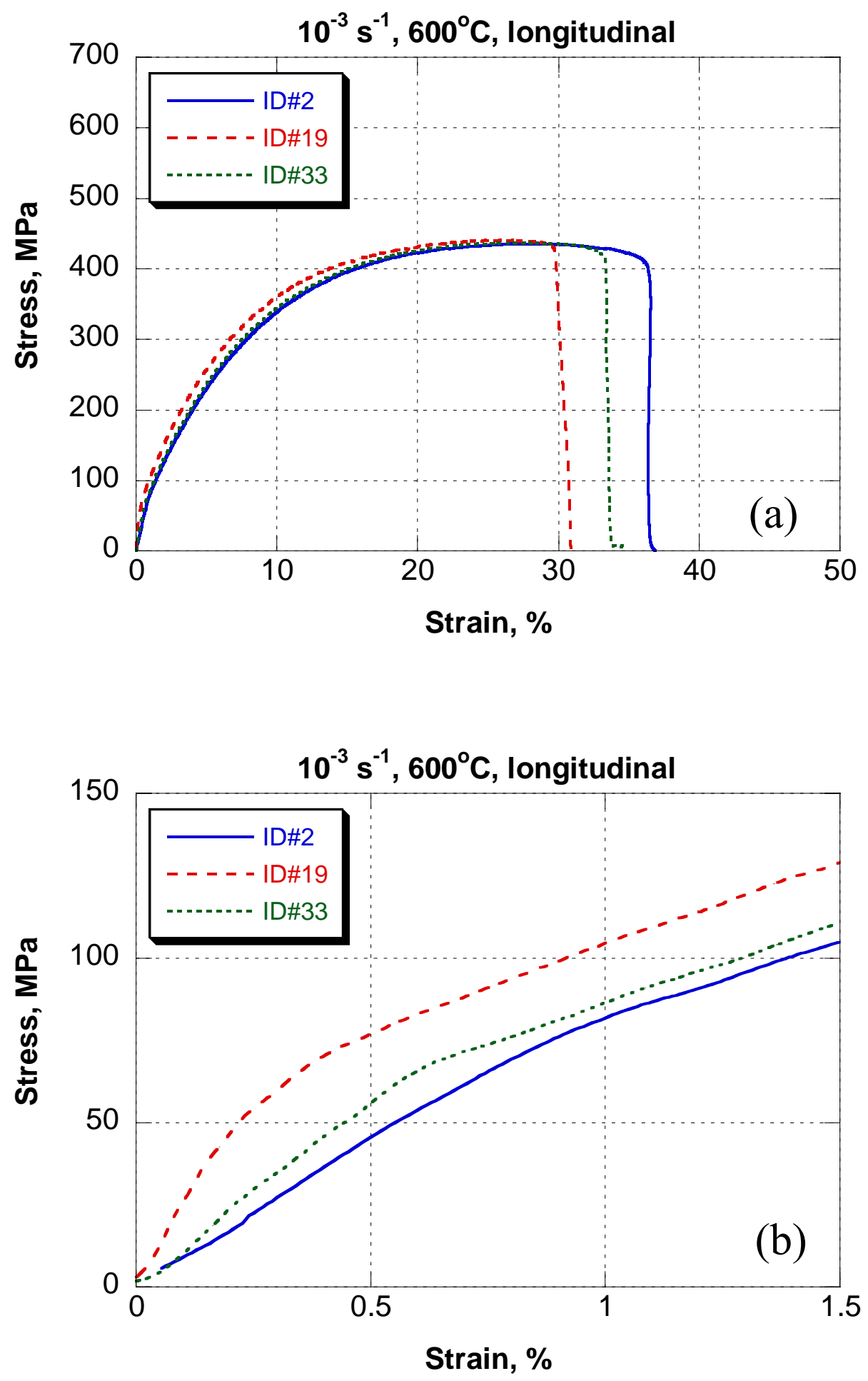

Fig. 4. Stress-strain curves at $10^{-3} \mathrm{~s}^{-1}$ and $600^{\circ} \mathrm{C}$, longitudinal specimen orientation, (a) full curves, (b) yield region. 

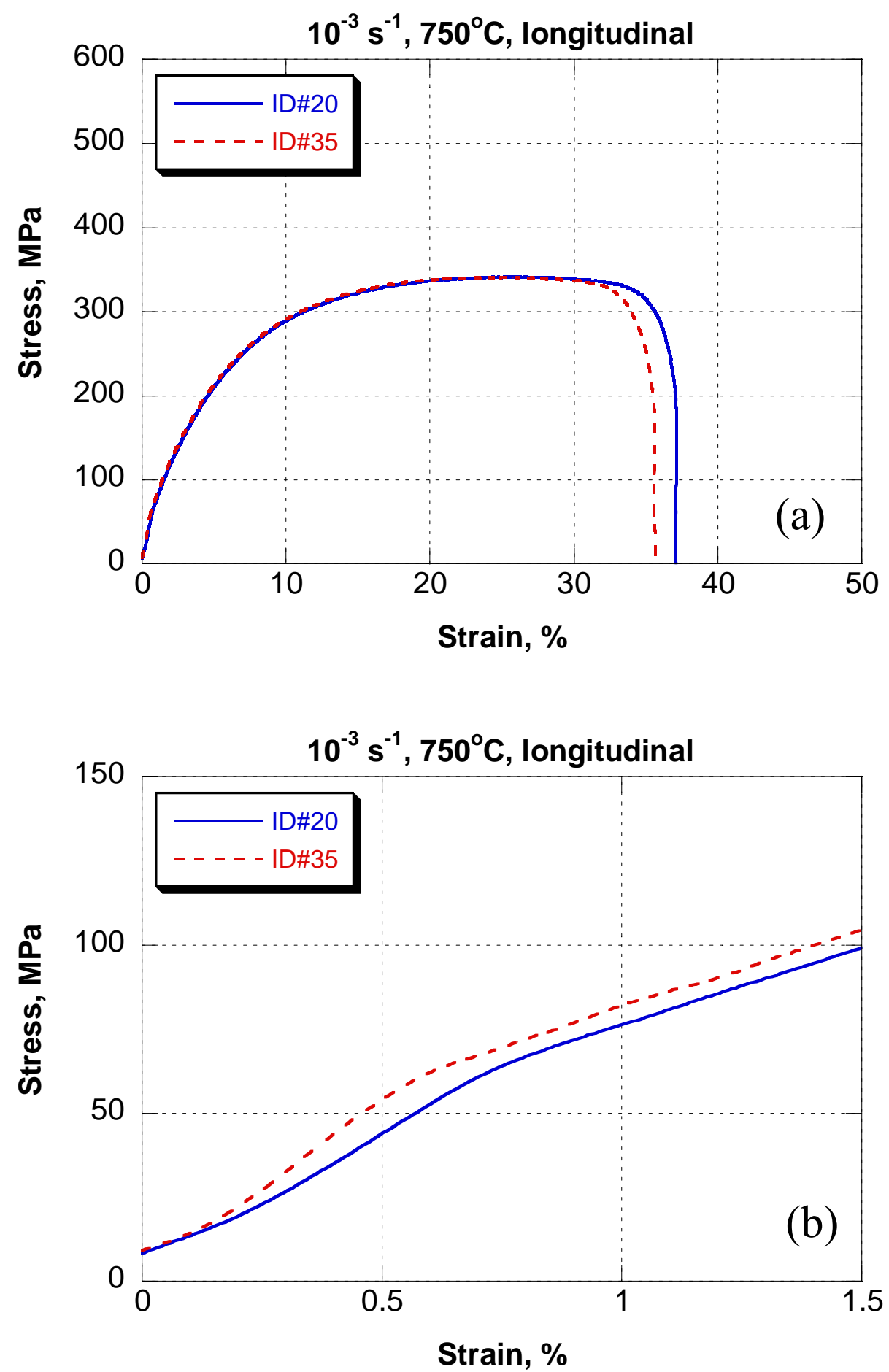

Fig. 5. Stress-strain curves at $10^{-3} \mathrm{~s}^{-1}$ and $750^{\circ} \mathrm{C}$, longitudinal specimen orientation, (a) full curves, (b) yield region. 

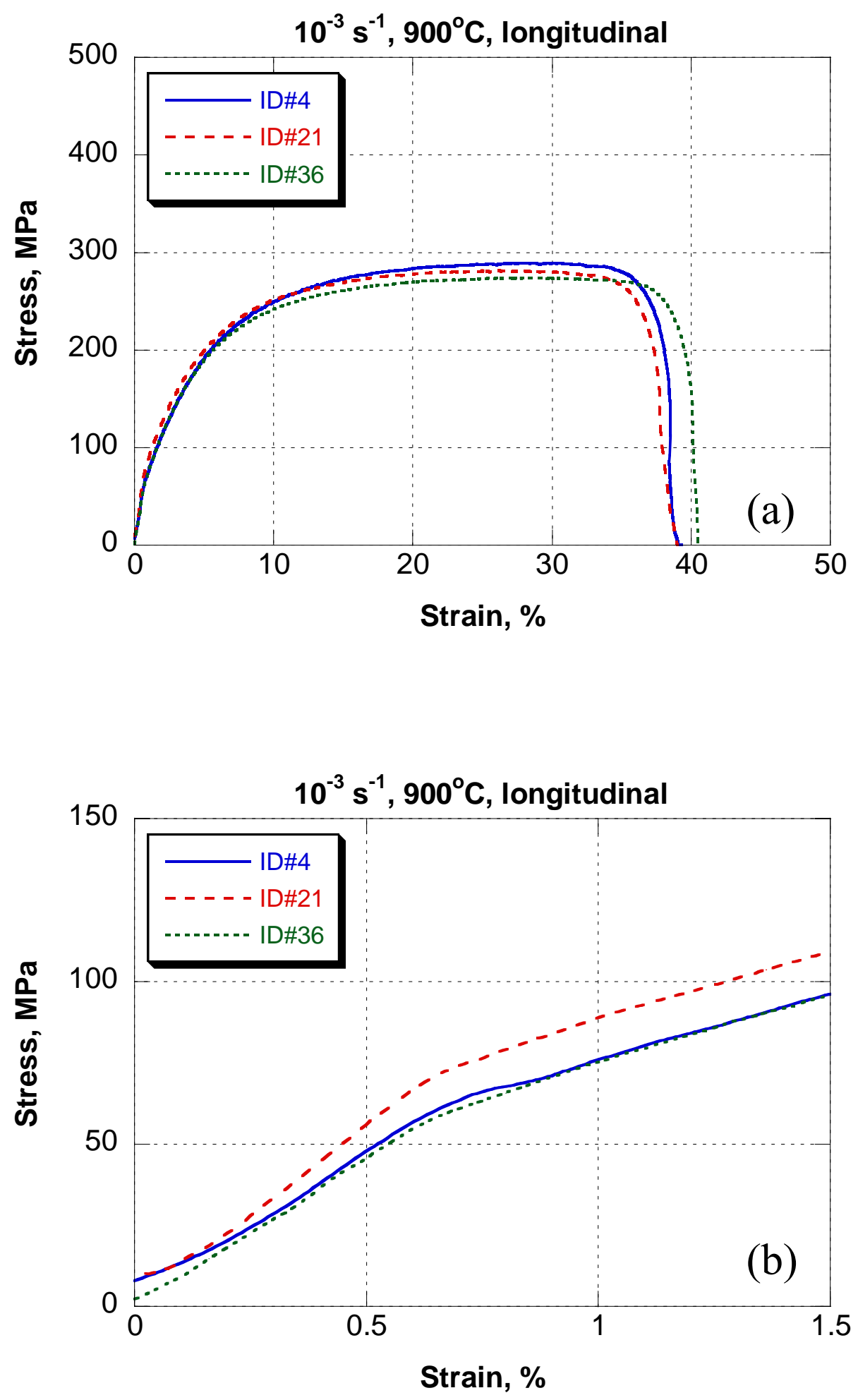

Fig. 6. Stress-strain curves at $10^{-3} \mathrm{~s}^{-1}$ and $900^{\circ} \mathrm{C}$, longitudinal specimen orientation, (a) full curves, (b) yield region. 

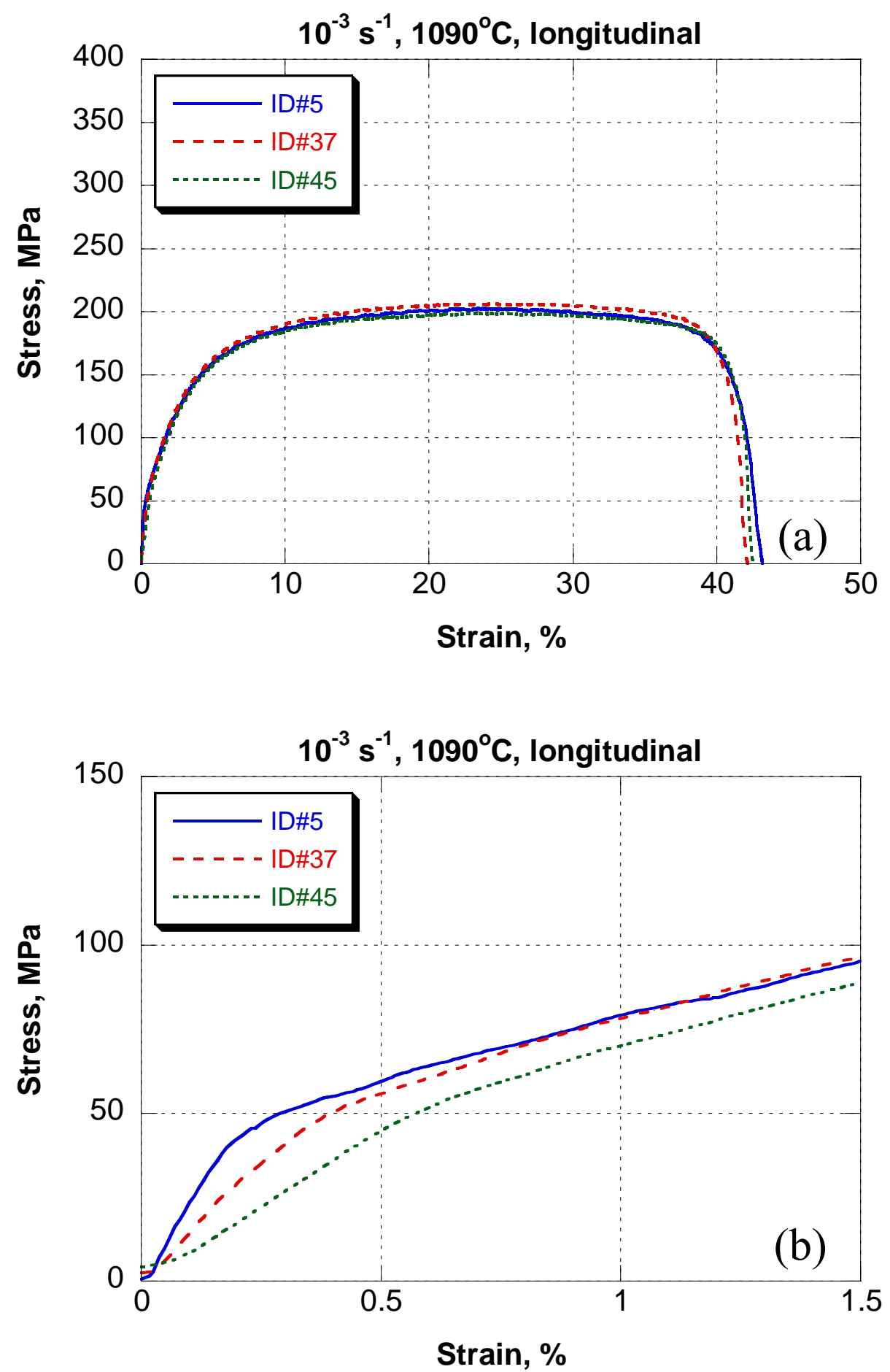

Fig. 7. Stress-strain curves at $10^{-3} \mathrm{~s}^{-1}$ and $1090^{\circ} \mathrm{C}$, longitudinal specimen orientation, (a) full curves, (b) yield region. 

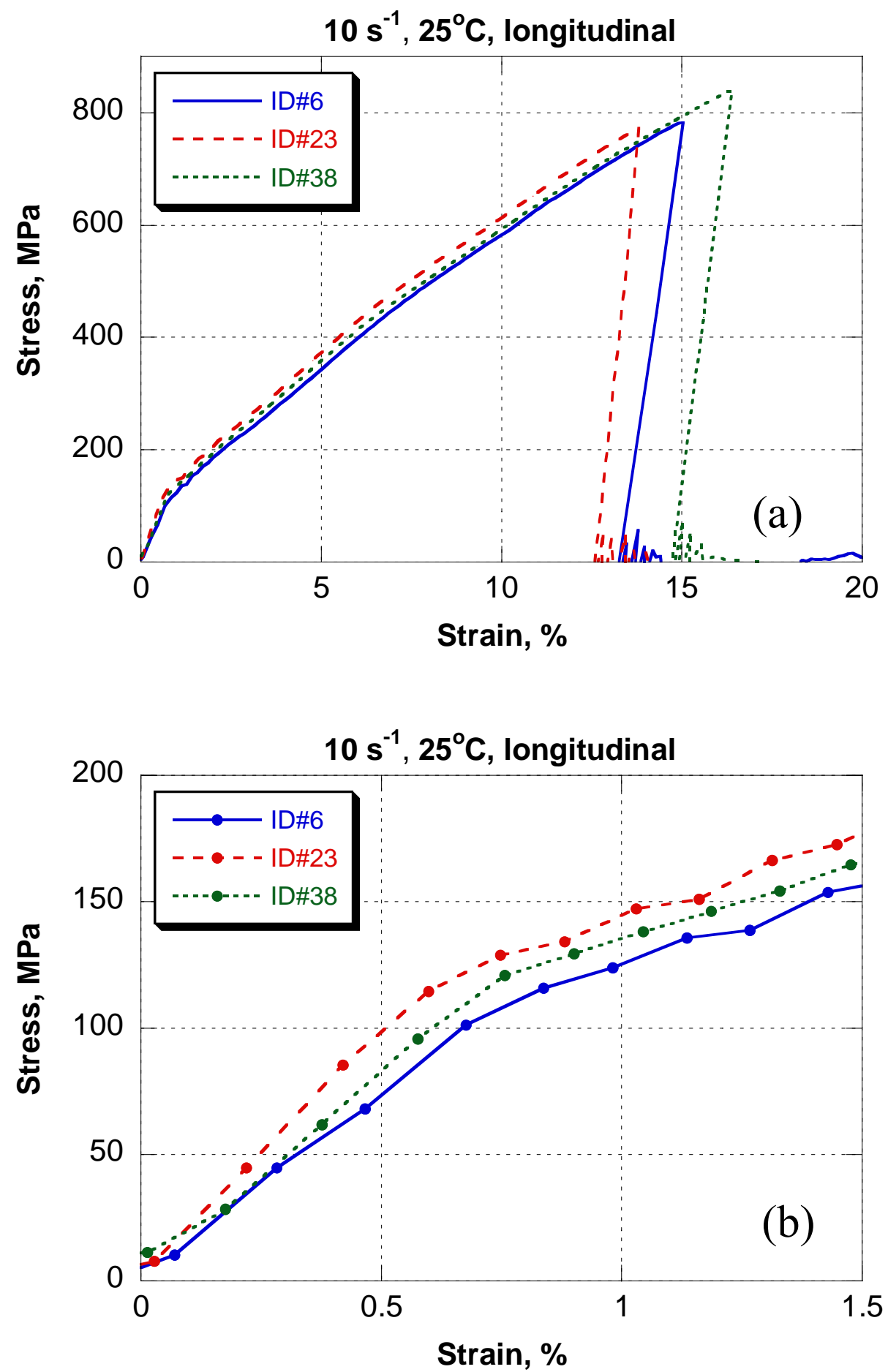

Fig. 8. Stress-strain curves at $10 \mathrm{~s}^{-1}$ and $25^{\circ} \mathrm{C}$, longitudinal specimen orientation, (a) full curves, (b) yield region. 

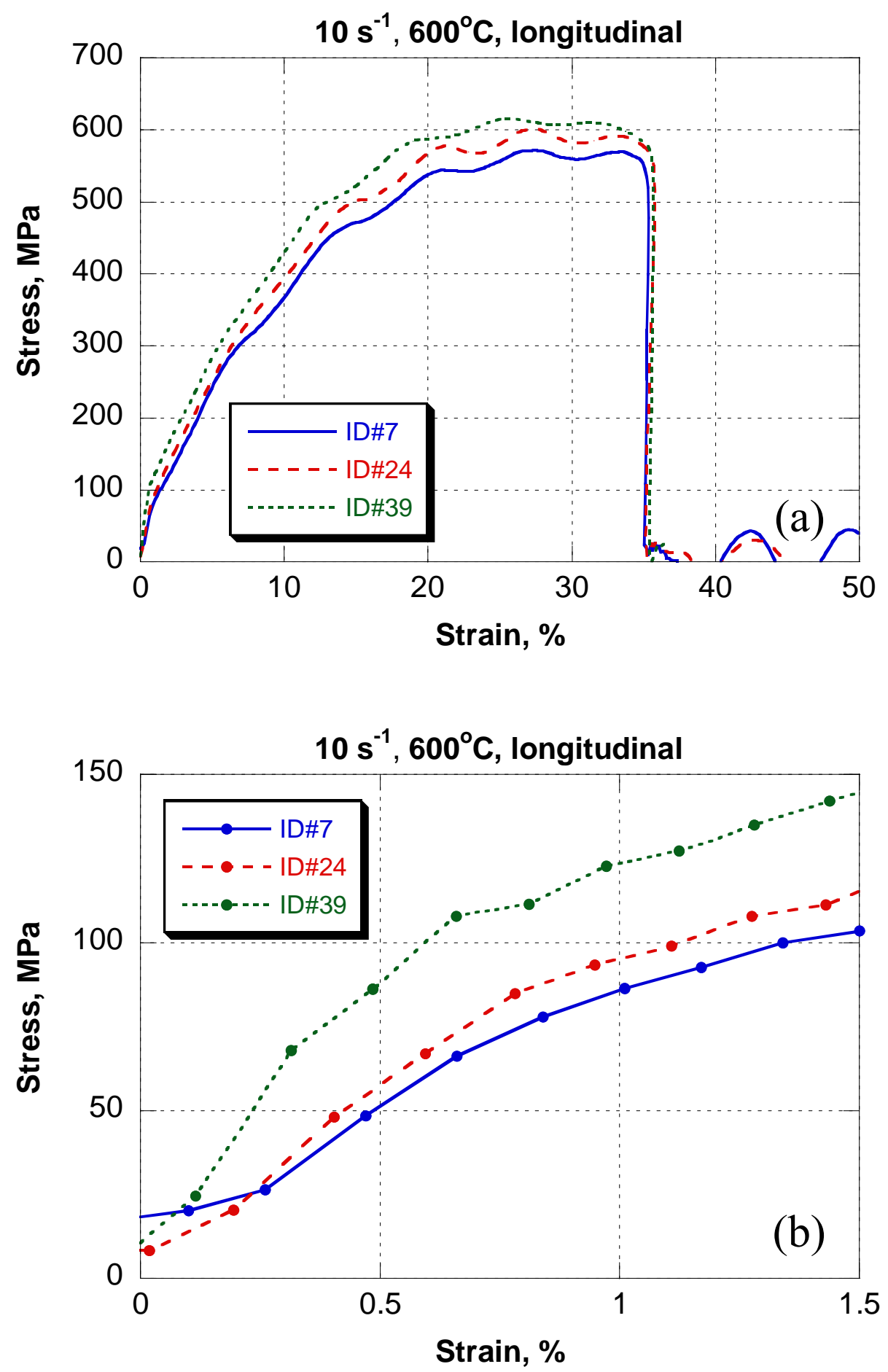

Fig. 9. Stress-strain curves at $10 \mathrm{~s}^{-1}$ and $600^{\circ} \mathrm{C}$, longitudinal specimen orientation, (a) full curves, (b) yield region. 

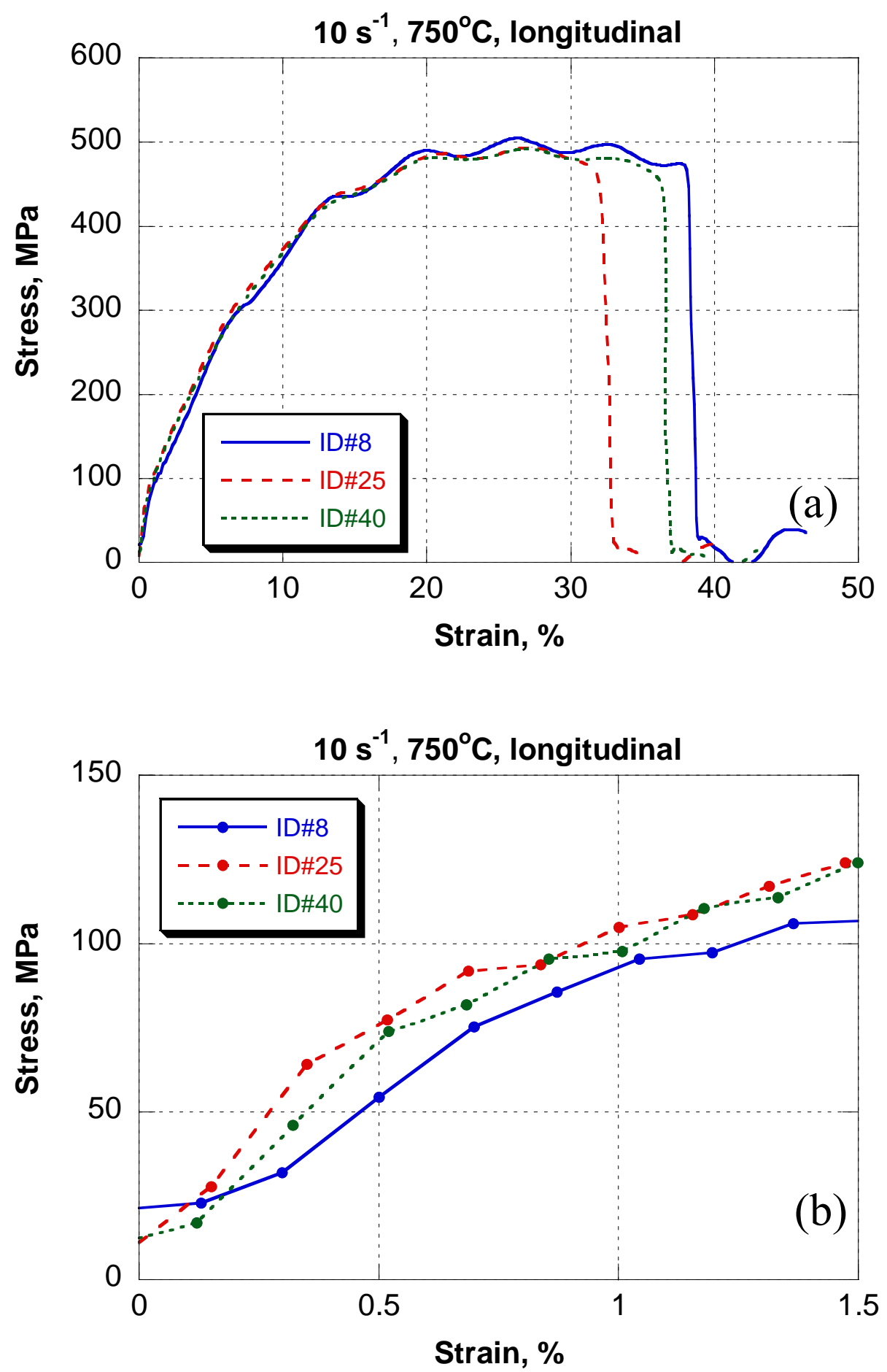

Fig. 10. Stress-strain curves at $10 \mathrm{~s}^{-1}$ and $750^{\circ} \mathrm{C}$, longitudinal specimen orientation, (a) full curves, (b) yield region. 

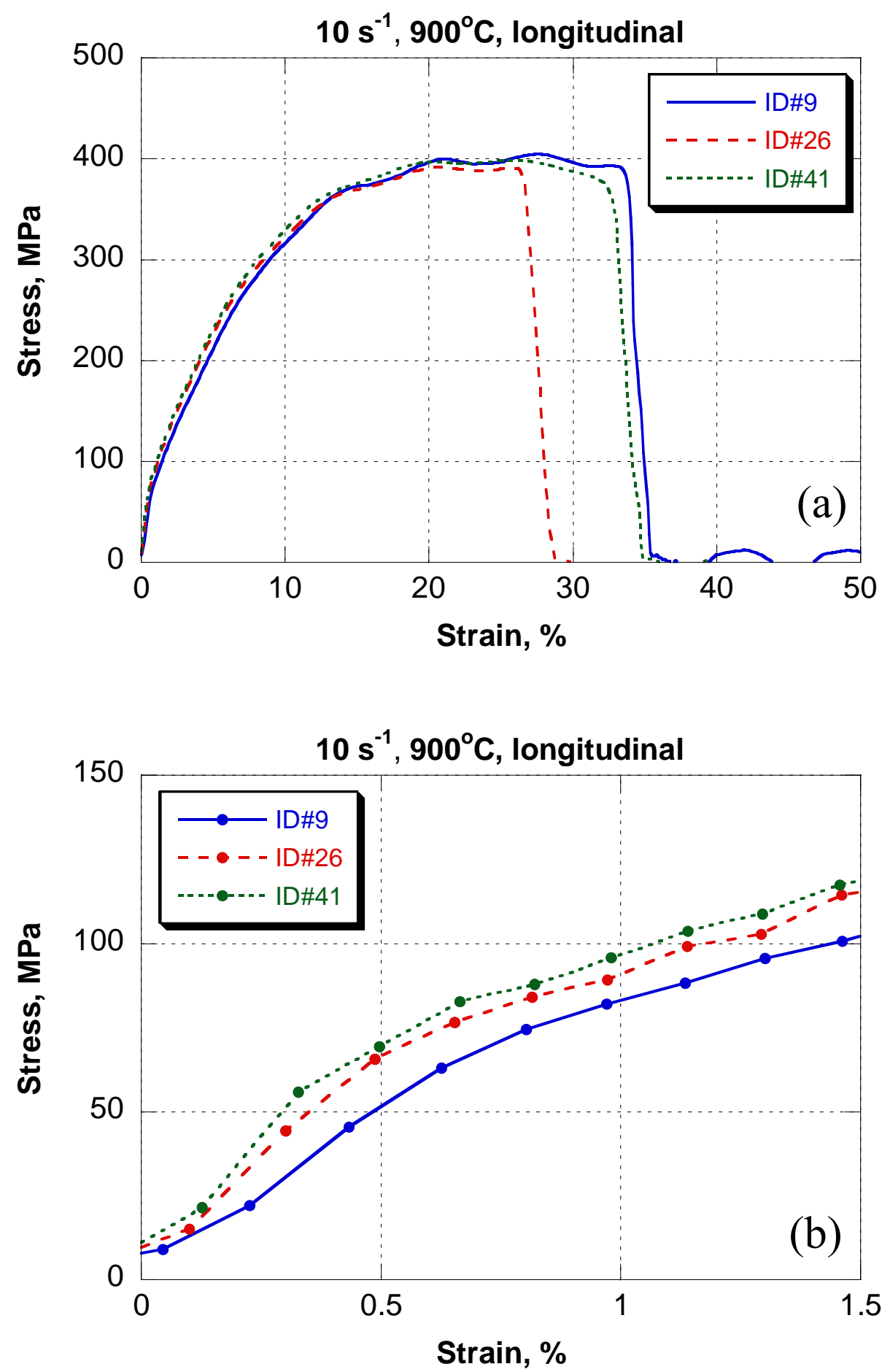

Fig. 11. Stress-strain curves at $10 \mathrm{~s}^{-1}$ and $900^{\circ} \mathrm{C}$, longitudinal specimen orientation, (a) full curves, (b) yield region. 

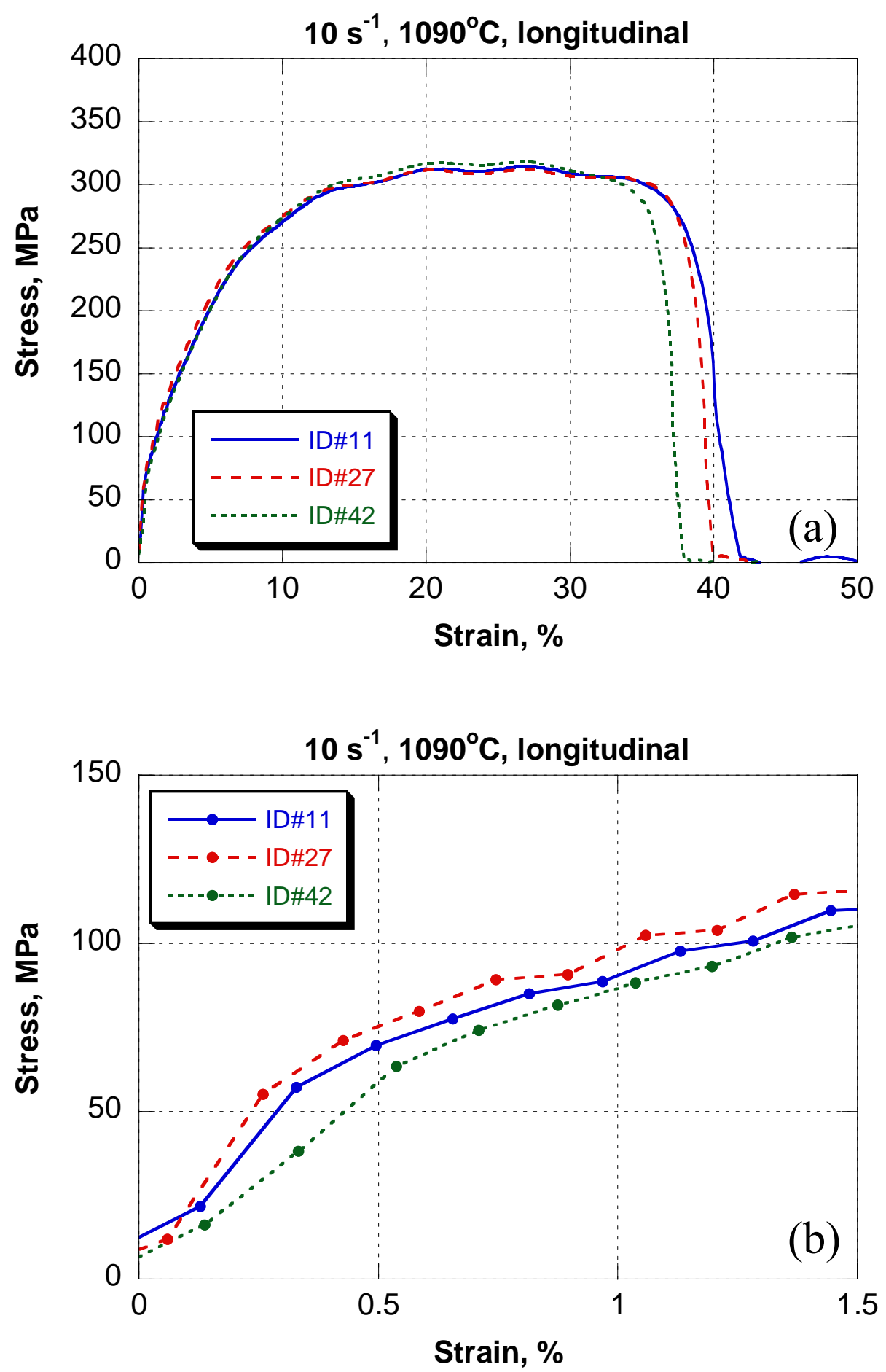

Fig. 12. Stress-strain curves at $10 \mathrm{~s}^{-1}$ and $1090^{\circ} \mathrm{C}$, longitudinal specimen orientation, (a) full curves, (b) yield region. 


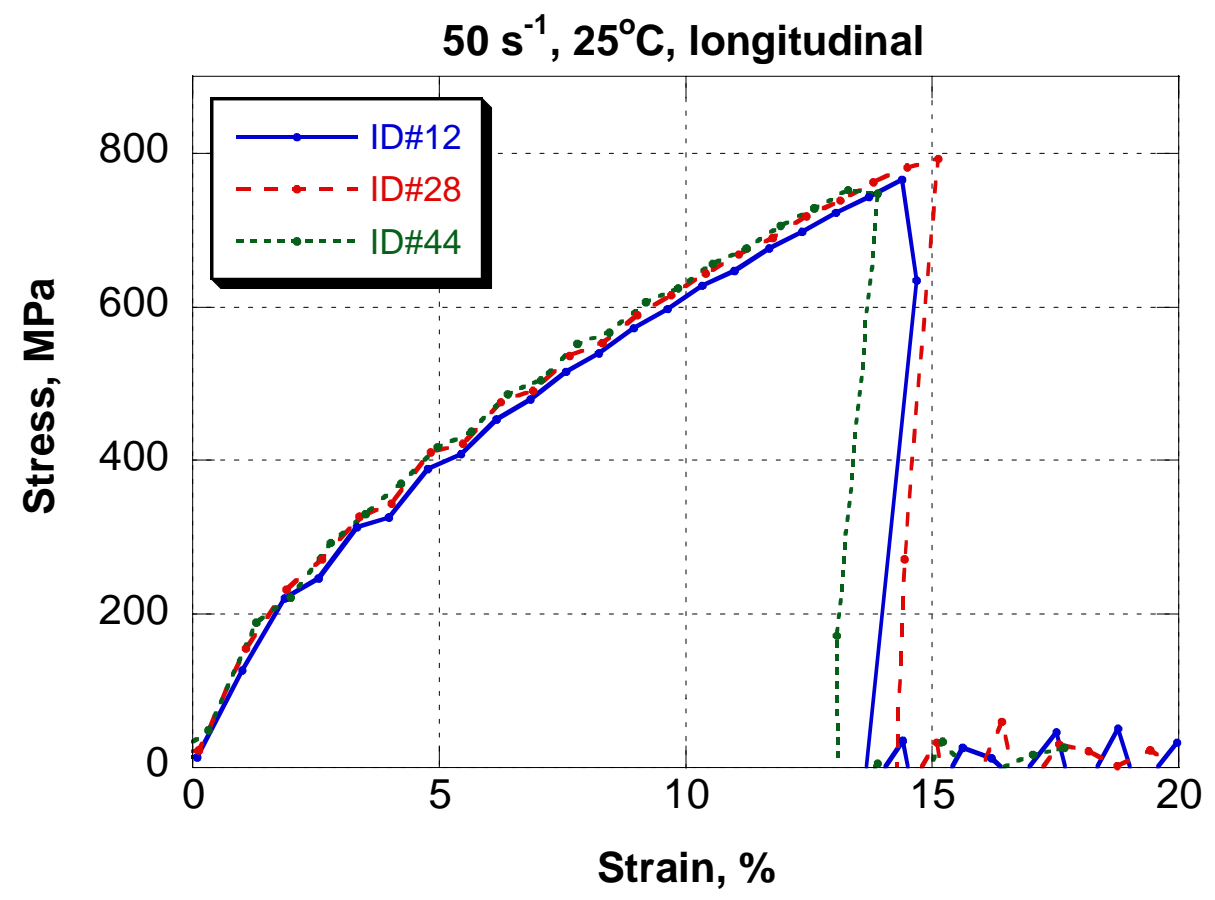

Fig. 13. Stress-strain curves at $50 \mathrm{~s}^{-1}$ and $25^{\circ} \mathrm{C}$, longitudinal specimen orientation.

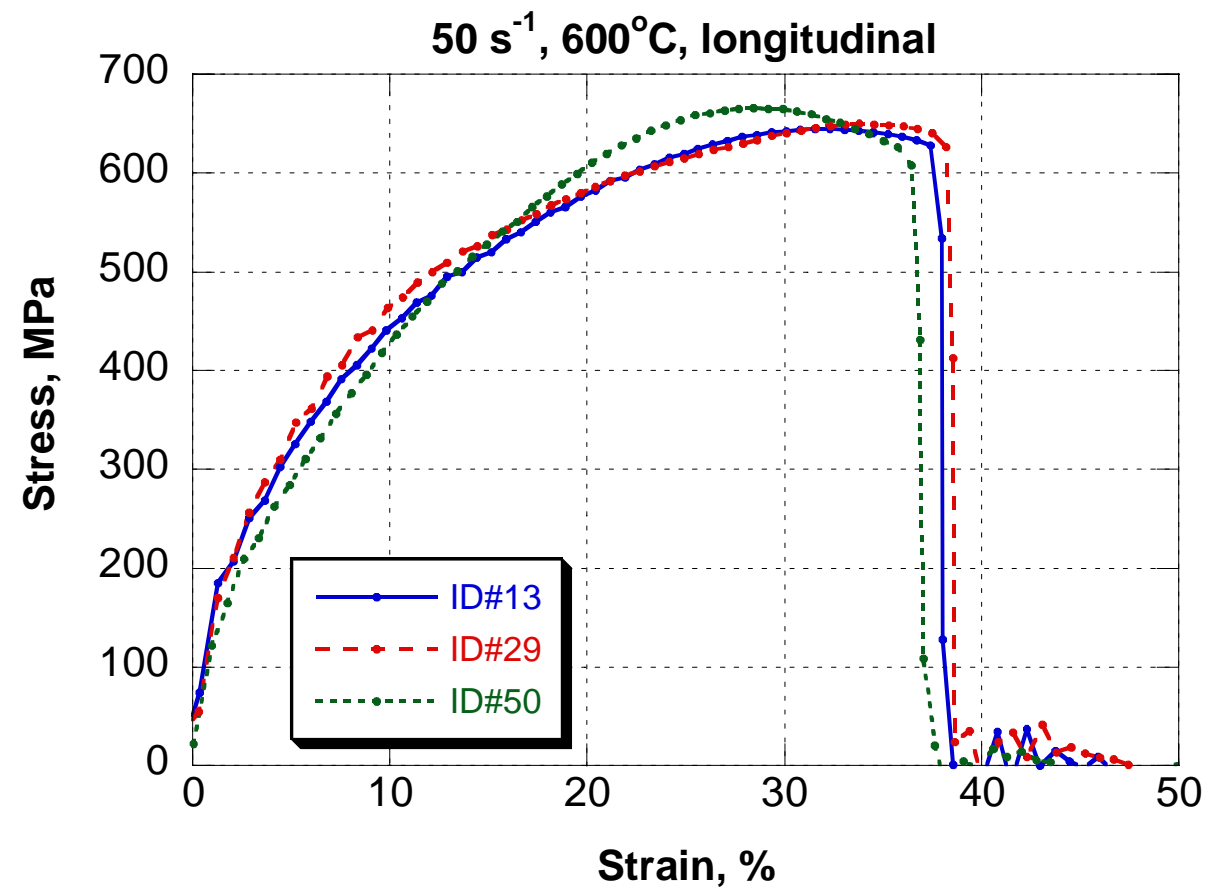

Fig. 14. Stress-strain curves at $50 \mathrm{~s}^{-1}$ and $600^{\circ} \mathrm{C}$, longitudinal specimen orientation. 


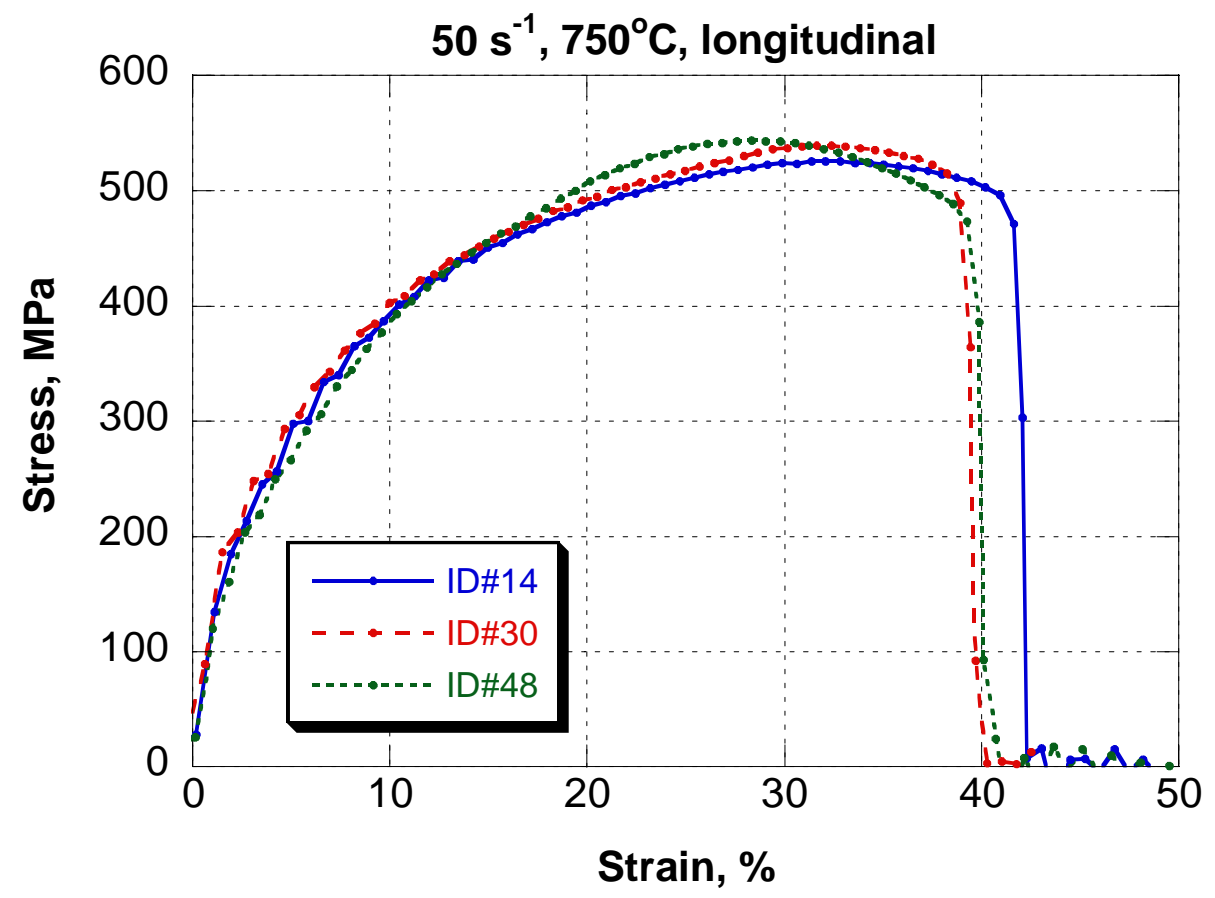

Fig. 15. Stress-strain curves at $50 \mathrm{~s}^{-1}$ and $750^{\circ} \mathrm{C}$, longitudinal specimen orientation.

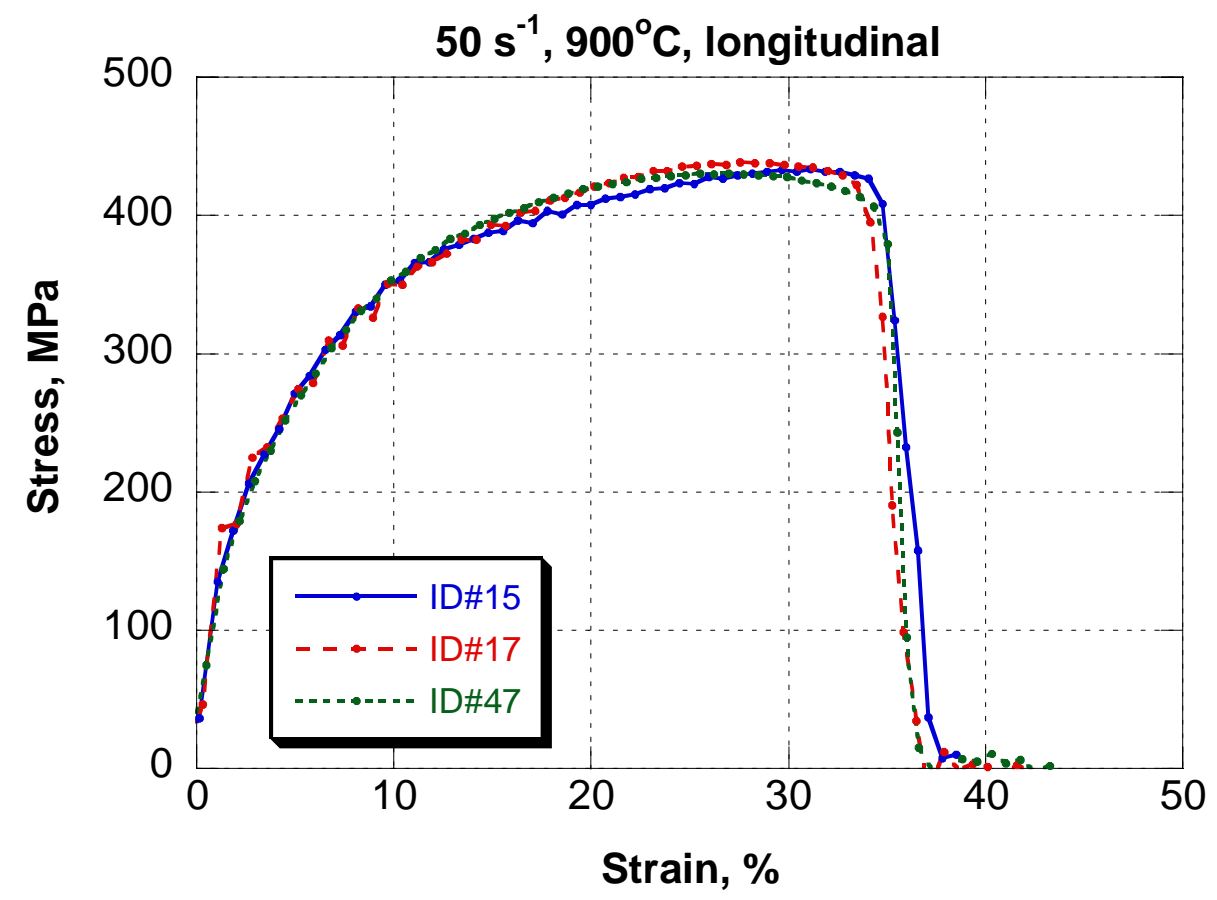

Fig. 16. Stress-strain curves at $50 \mathrm{~s}^{-1}$ and $900^{\circ} \mathrm{C}$, longitudinal specimen orientation. 


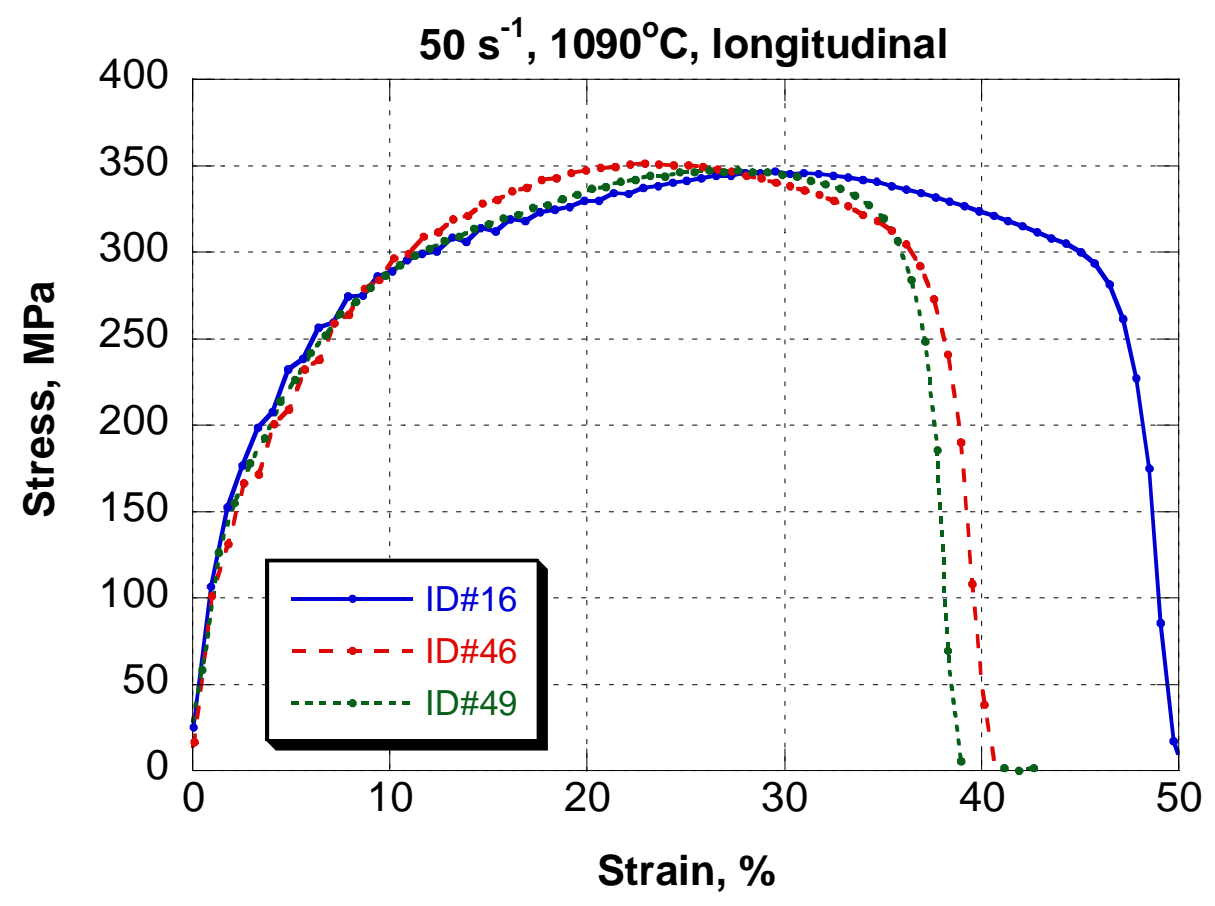

Fig. 17. Stress-strain curves at $50 \mathrm{~s}^{-1}$ and $1090^{\circ} \mathrm{C}$, longitudinal specimen orientation. 

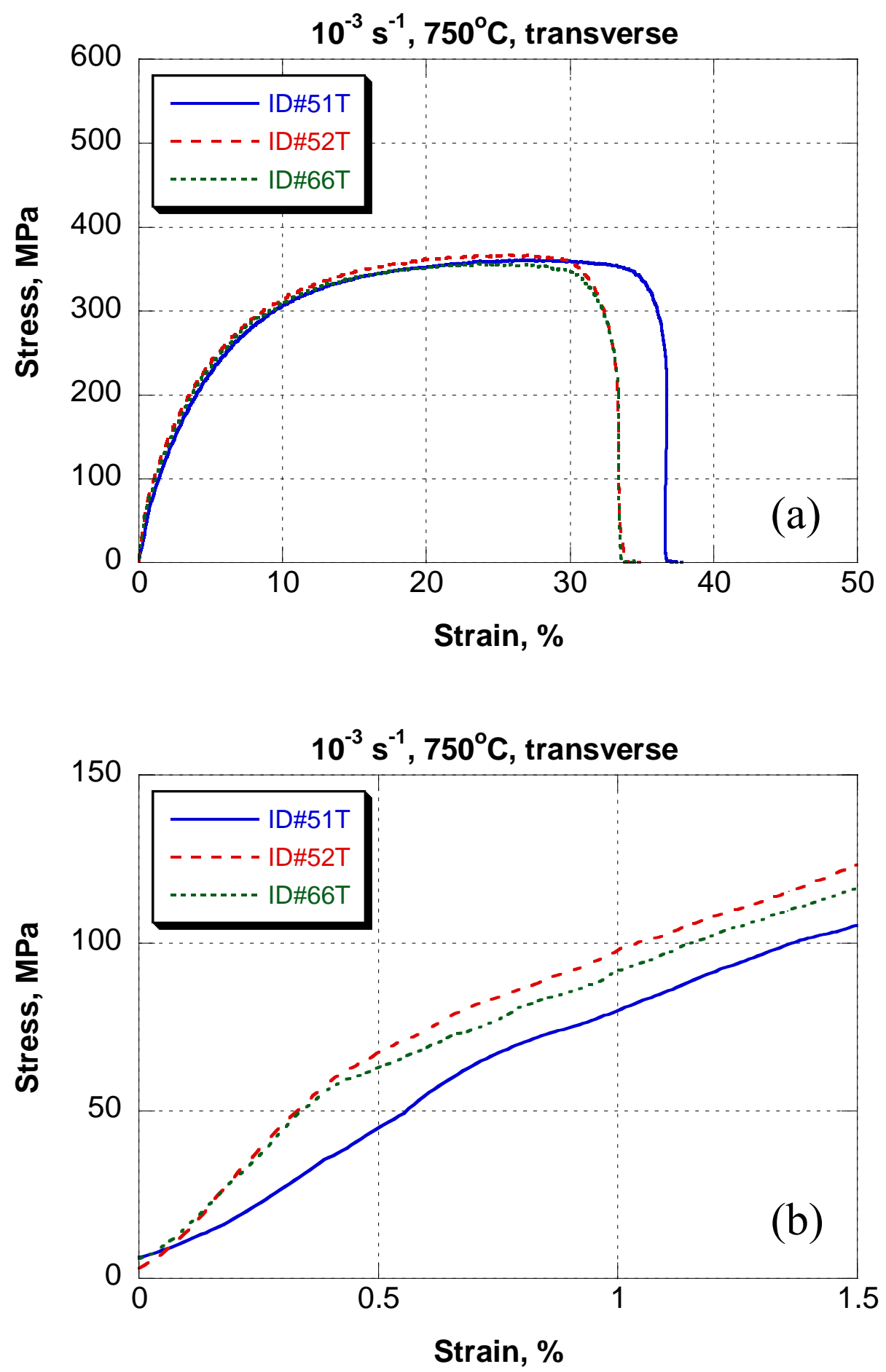

Fig. 18. Stress-strain curves at $10^{-3} \mathrm{~s}^{-1}$ and $750^{\circ} \mathrm{C}$, transverse specimen orientation, (a) full curves, (b) yield region. 

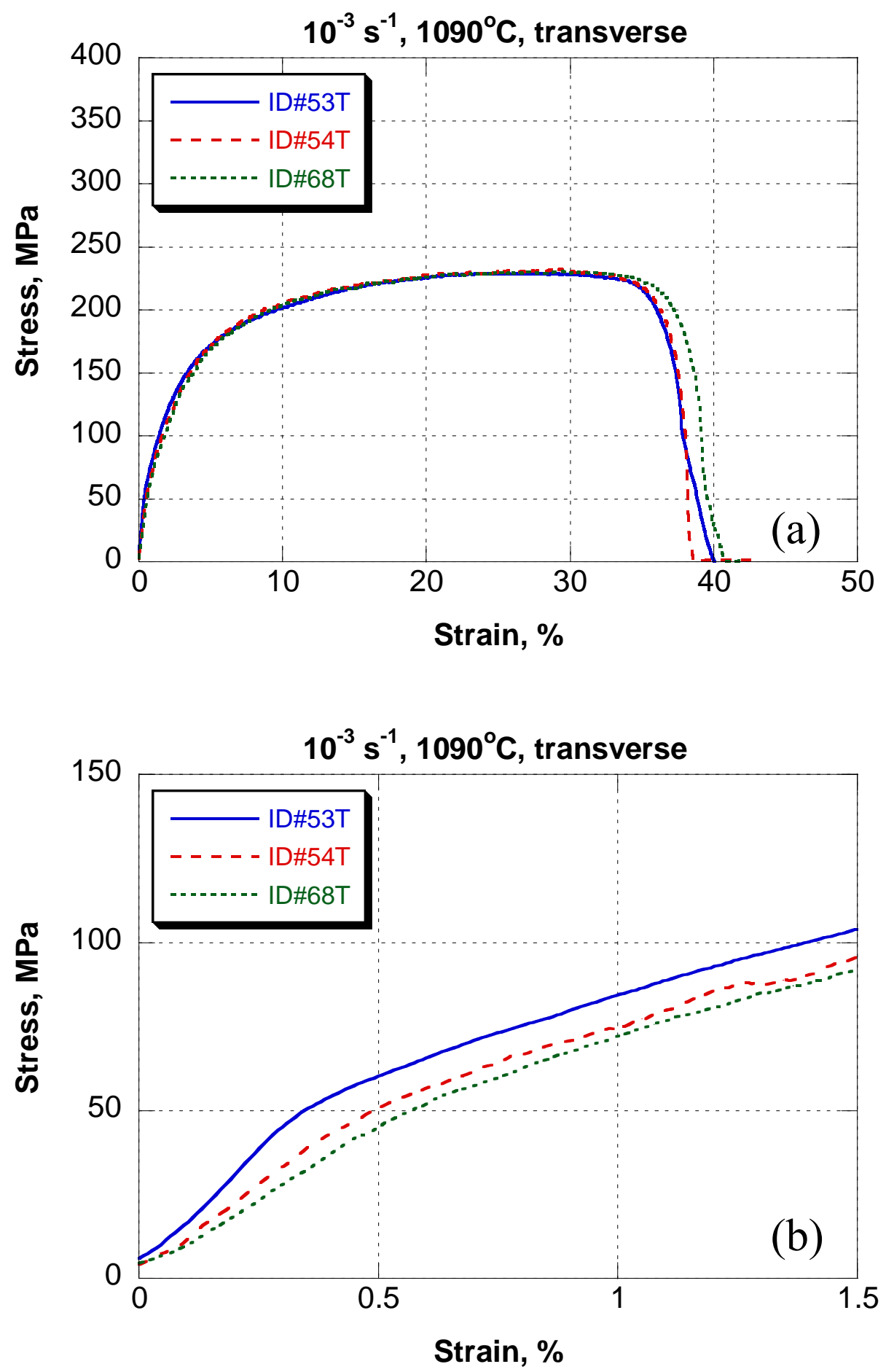

Fig. 19. Stress-strain curves at $10^{-3} \mathrm{~s}^{-1}$ and $1090^{\circ} \mathrm{C}$, transverse specimen orientation, (a) full curves, (b) yield region. 

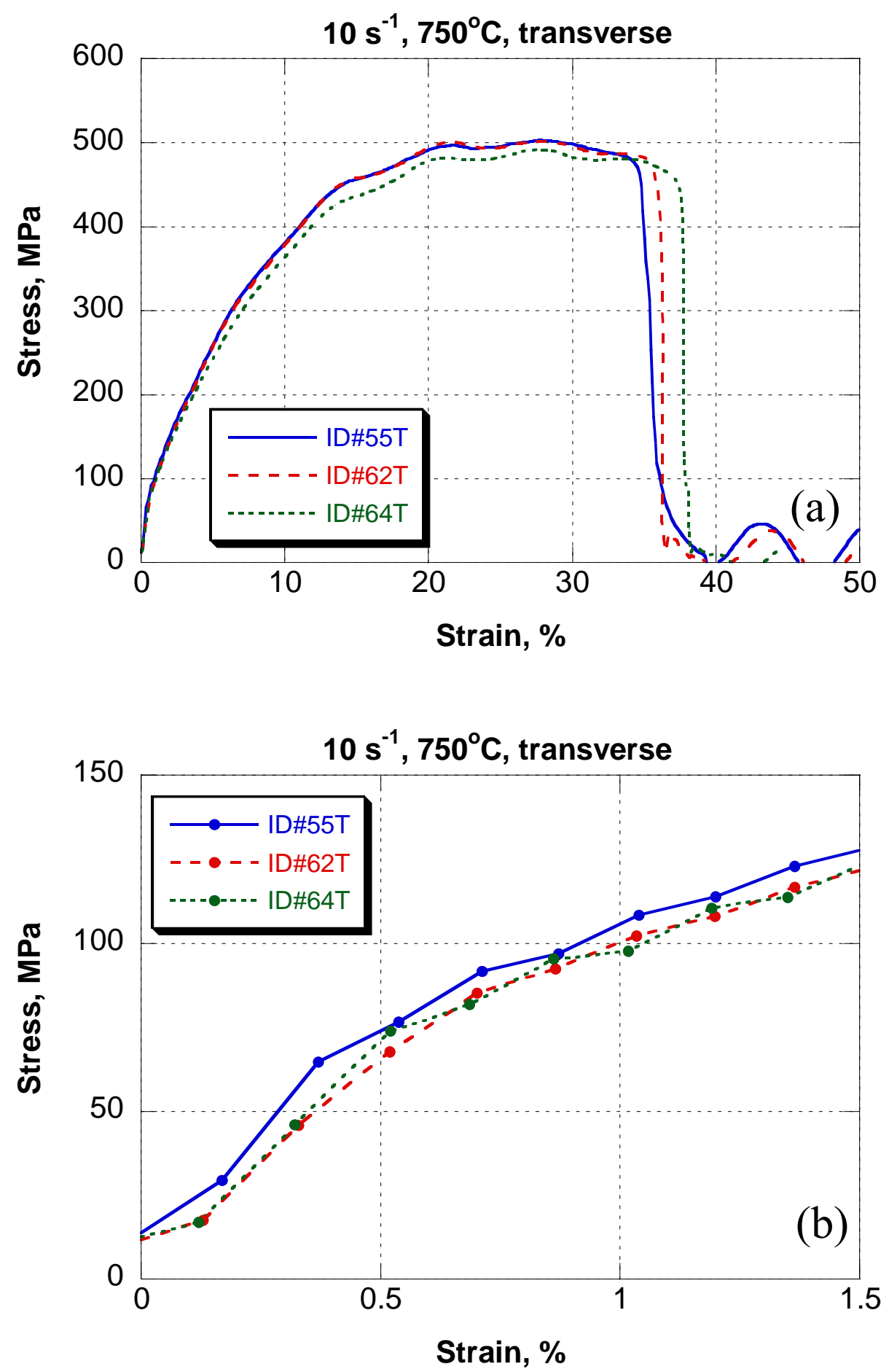

Fig. 20. Stress-strain curves at $10 \mathrm{~s}^{-1}$ and $750^{\circ} \mathrm{C}$, transverse specimen orientation, (a) full curves, (b) yield region. 

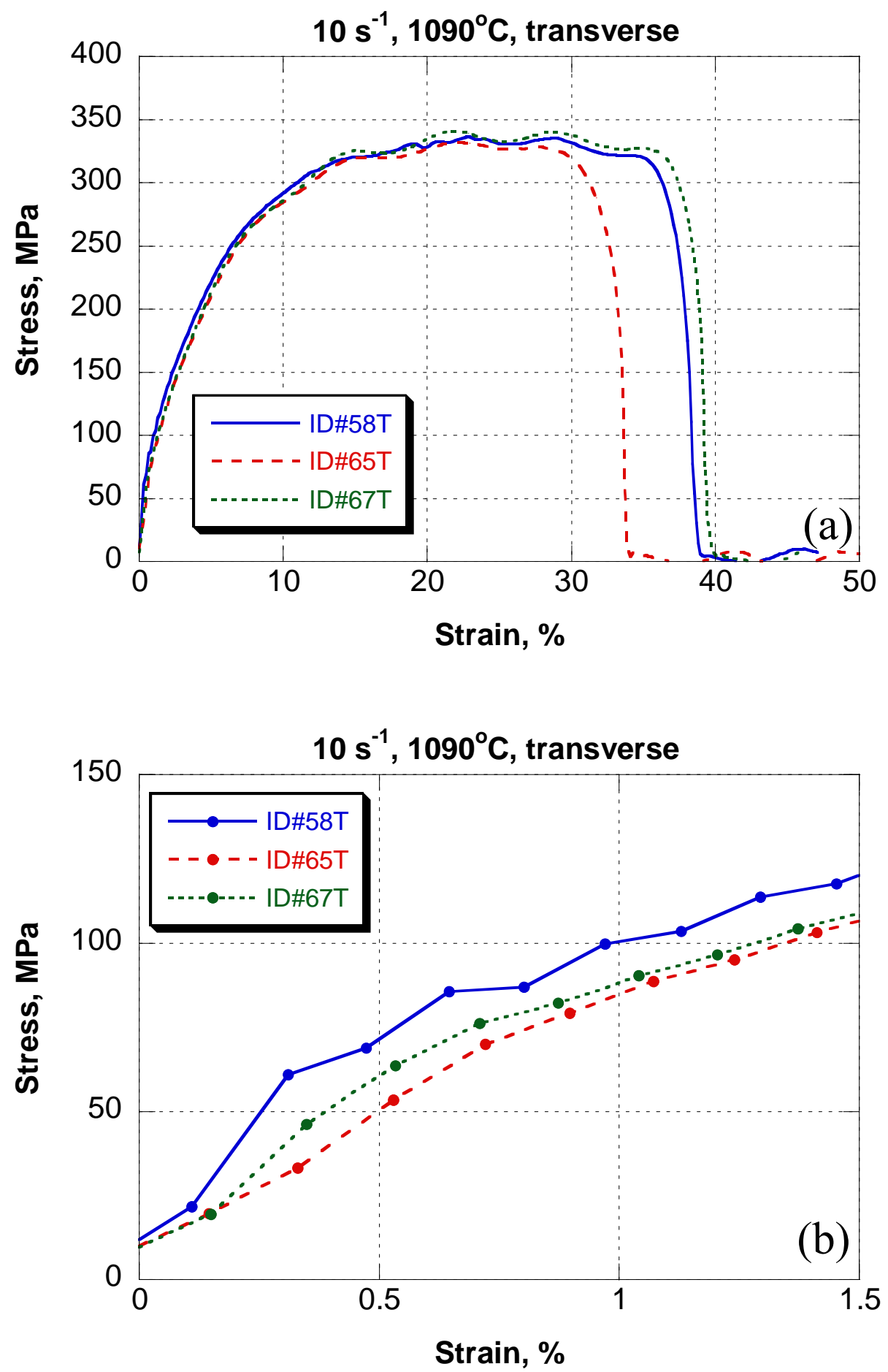

Fig. 21. Stress-strain curves at $10 \mathrm{~s}^{-1}$ and $1090^{\circ} \mathrm{C}$, transverse specimen orientation, (a) full curves, (b) yield region. 


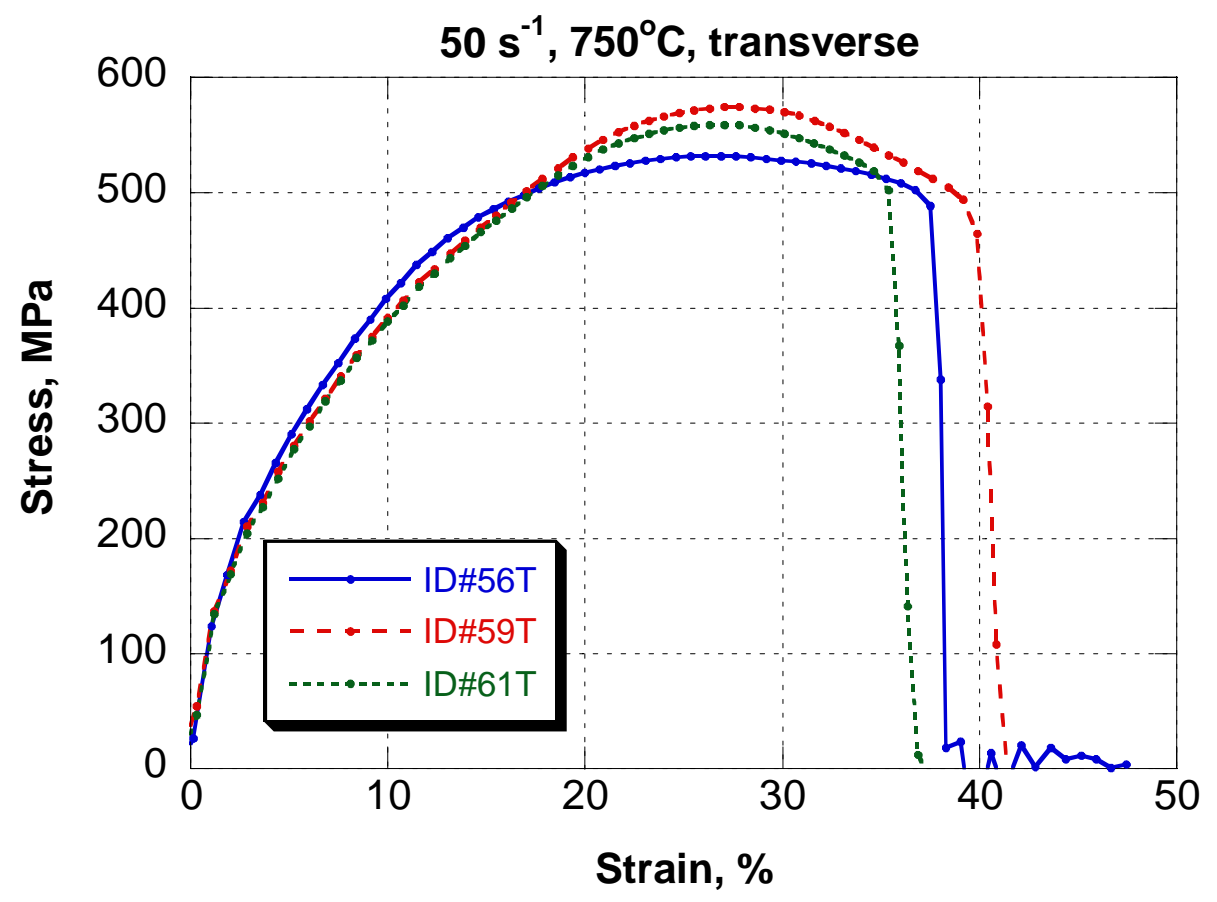

Fig. 22. Stress-strain curves at $50 \mathrm{~s}^{-1}$ and $750^{\circ} \mathrm{C}$, transverse specimen orientation.

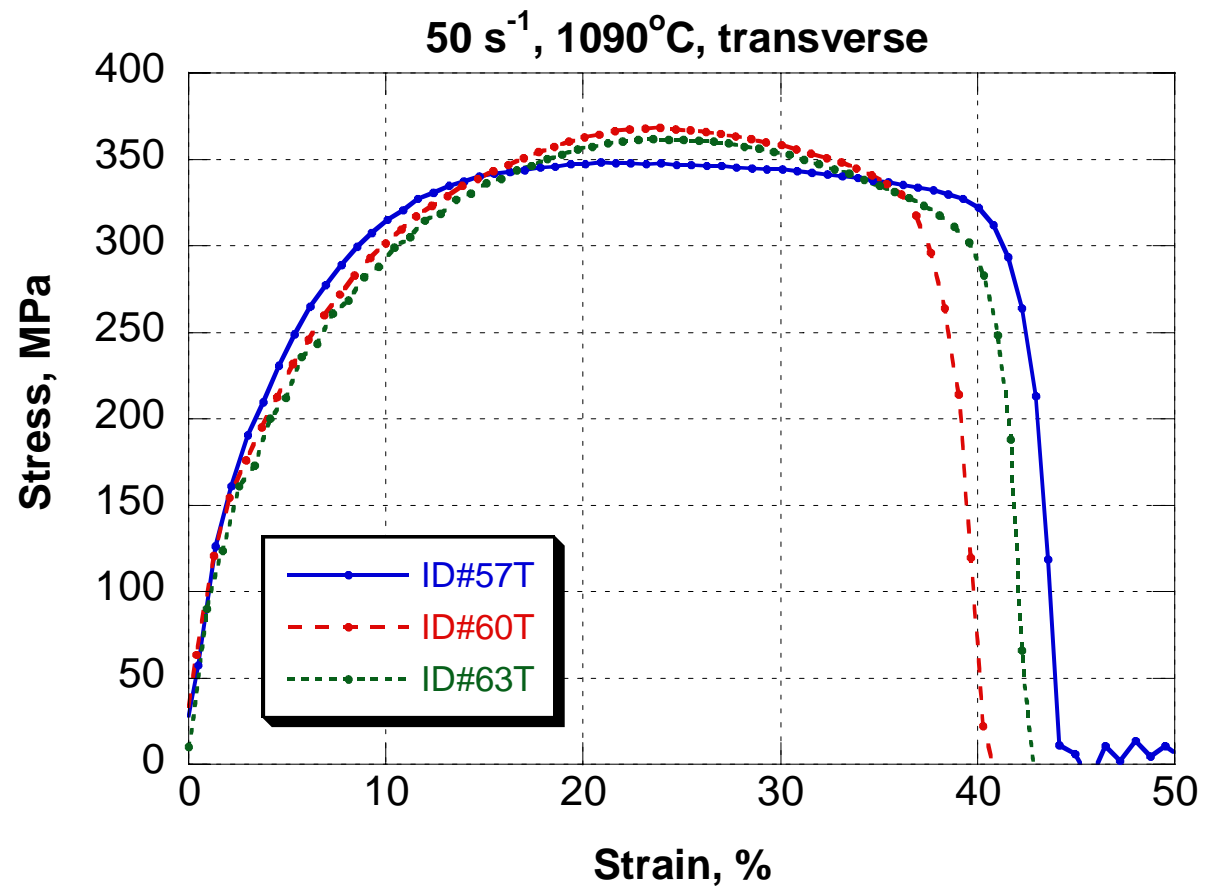

Fig. 23. Stress-strain curves at $50 \mathrm{~s}^{-1}$ and $1090^{\circ} \mathrm{C}$, transverse specimen orientation. 


\section{YIELD STRESS, ULTIMATE TENSILE STRESS, FRACTURE STRAIN, REDUCTION IN AREA}

The $0.2 \%$ yield stresses (YS), ultimate tensile stresses (UTS) and fracture strains (elongations to fracture) were evaluated from the curves in Figs. 3-23. These values as well as the reduction in area (RA) values are summarized in Tables IV and V. Table VI compares the average values for nominally identical tests, for longitudinal as well as transverse specimens. The corresponding plots are shown in Figs. 24-27. Typical standard deviations, in \% of the average value, were $5 \%$ for the YS, $2 \%$ for the UTS, $6 \%$ for the ductility, and $6 \%$ for the RA. Figure 24 shows that the yield stress decreases as the temperature increases, and that higher strain rates result in higher yield stresses, i.e., the material is strain rate sensitive. The yield stress values at $10^{-3} \mathrm{~s}^{-1}$ tend to be slightly lower and less scattered than the corresponding DOP-26 values shown in George et al. [10]. The strain rate sensitivity of DOP-26 is clearly illustrated for the UTS values in Fig. 25. As compared to George et al. [10], the room temperature UTS is higher, whereas the UTS values at $>600^{\circ} \mathrm{C}$ tend to be lower. The fracture strain increases substantially when the test temperature is increased from ambient to $600^{\circ} \mathrm{C}$ (Fig. 26). As the temperature is increased further, one observes a slight trend towards increased fracture strains. Within the scatter of the data, the fracture strains at $600^{\circ} \mathrm{C}$ and above do not appear to depend on the strain rate. However, this does not preclude a reduction in the fracture strain for strain rates well in excess of $50 \mathrm{~s}^{-1}$. The reduction in area is more sensitive to the temperature and strain rate than the fracture strain. For example, while the RA at $900^{\circ} \mathrm{C}$ and $10^{-3} \mathrm{~s}^{-1}$ is close to $100 \%$, an increase in the strain rate to 10 or $50 \mathrm{~s}^{-1}$ reduces its value by approximately $50 \%$ (Fig. 27). Within the window of temperature and strain rates examined, the mechanical properties do not appear to be sensitive to the testing orientation, although there may be a trend towards lower ductility for the transverse specimens.

Heestand et al. [12] previously examined the effect of the testing orientation on the ductility at $925^{\circ} \mathrm{C}$ (Table VII). The strain rate, $0.67 \mathrm{~s}^{-1}$, was intermediate between the values of $1 \times 10^{-3}$ and $10 \mathrm{~s}^{-1}$ in the present report. Heestand et al.'s material was not recrystallized - it was only stress-relieved by annealing for 1 hour at $1025^{\circ} \mathrm{C}$. Not surprisingly, the UTS values, approximately $700 \mathrm{MPa}$, were higher than the approximately $400 \mathrm{MPa}$ in the present report. Similarly, the stress-relieved material is much less ductile than the fully recrystallized material.

In disagreement with the present results, Heestand et al.'s data indicates a significantly lower ductility for the transverse orientation as compared to the longitudinal one. One reason for this difference may be the fact that the specimens in the present work were fully recrystallized by annealing for 1 hour at $1375^{\circ} \mathrm{C}$. The recrystallization may have alleviated the anisotropy, as compared to the stress-relieved compositions. However, it cannot be ruled out that anisotropy might be observed even in fully recrystallized material at strain rates well above $50 \mathrm{~s}^{-1}$. 
Table IV. Longitudinal DOP-26 iridium (Sheet identification K3-14) at different strain rates and temperatures (T): $\mathbf{0 . 2 \%}$ yield stress (YS), ultimate tensile stress (UTS), fracture strain (elongation to fracture), and reduction in area (RA)

\begin{tabular}{|c|c|c|c|c|c|c|}
\hline ID\# & Strain Rate, $\mathrm{s}^{-1}$ & $\mathrm{~T},{ }^{\circ} \mathrm{C}$ & $\begin{array}{c}0.2 \% \mathrm{YS} \\
\mathrm{MPa}\end{array}$ & $\begin{array}{l}\text { UTS, } \\
\text { MPa }\end{array}$ & $\begin{array}{l}\text { Fracture } \\
\text { strain, \% }\end{array}$ & $\mathrm{RA}, \%$ \\
\hline 1 & $1 \times 10^{-3}$ & 25 & 119 & 690 & 8.9 & 5.9 \\
\hline 32 & $1 \times 10^{-3}$ & 25 & 126 & 700 & 8.9 & 11.2 \\
\hline 43 & $1 \times 10^{-3}$ & 25 & 127 & 769 & 10.5 & 7.3 \\
\hline 2 & $1 \times 10^{-3}$ & 600 & 92 & 436 & 32.6 & 59.8 \\
\hline 19 & $1 \times 10^{-3}$ & 600 & 78 & 441 & 28.6 & 49.7 \\
\hline 33 & $1 \times 10^{-3}$ & 600 & 83 & 438 & 30.3 & 53.8 \\
\hline 20 & $1 \times 10^{-3}$ & 750 & 83 & 342 & 33.2 & 98.5 \\
\hline 35 & $1 \times 10^{-3}$ & 750 & 77 & 341 & 32.2 & 88.8 \\
\hline 4 & $1 \times 10^{-3}$ & 900 & 75 & 289 & 35.1 & 91.1 \\
\hline 21 & $1 \times 10^{-3}$ & 900 & 88 & 282 & 34.9 & 97.2 \\
\hline 36 & $1 \times 10^{-3}$ & 900 & 77 & 274 & 36.8 & 93.6 \\
\hline 5 & $1 \times 10^{-3}$ & 1090 & 57 & 203 & 40.0 & 99.2 \\
\hline 37 & $1 \times 10^{-3}$ & 1090 & 62 & 206 & 39.1 & 95.3 \\
\hline 45 & $1 \times 10^{-3}$ & 1090 & 70 & 199 & 39.0 & 97.2 \\
\hline 6 & 10 & 25 & 133 & 782 & 9.7 & 10.2 \\
\hline 23 & 10 & 25 & 133 & 772 & 10.0 & 9.8 \\
\hline 38 & 10 & 25 & 137 & 838 & 11.4 & 10.2 \\
\hline 7 & 10 & 600 & 90 & 565 & 30.8 & 43.1 \\
\hline 24 & 10 & 600 & 96 & 590 & 32.2 & 42.6 \\
\hline 39 & 10 & 600 & 109 & 612 & 33.4 & 36.6 \\
\hline 8 & 10 & 750 & 96 & 496 & 34.6 & 54.2 \\
\hline 25 & 10 & 750 & 92 & 486 & 30.0 & 55.2 \\
\hline 40 & 10 & 750 & 96 & 485 & 33.9 & 53.7 \\
\hline 9 & 10 & 900 & 84 & 400 & 31.2 & 57.9 \\
\hline 26 & 10 & 900 & 81 & 390 & 24.9 & 53.8 \\
\hline 41 & 10 & 900 & 84 & 397 & 31.2 & 65.0 \\
\hline 11 & 10 & 1090 & 76 & 312 & 37.1 & 97.1 \\
\hline 27 & 10 & 1090 & 79 & 310 & 37.0 & 88.7 \\
\hline 42 & 10 & 1090 & 83 & 317 & 33.9 & 95.1 \\
\hline 12 & 50 & 25 & & 765 & 9.6 & 9.2 \\
\hline 28 & 50 & 25 & & 793 & 9.9 & 9.0 \\
\hline 44 & 50 & 25 & & 753 & 8.9 & 8.9 \\
\hline 13 & 50 & 600 & & 645 & 33.9 & 38.4 \\
\hline 29 & 50 & 600 & & 650 & 34.9 & 38.7 \\
\hline 50 & 50 & 600 & & 666 & 33.1 & 44.2 \\
\hline 14 & 50 & 750 & & 526 & 38.7 & 49.2 \\
\hline 30 & 50 & 750 & & 539 & 36.3 & 49.4 \\
\hline 48 & 50 & 750 & & 543 & 36.6 & 51.3 \\
\hline 15 & 50 & 900 & & 433 & 32.9 & 58.4 \\
\hline 17 & 50 & 900 & & 438 & 32.2 & 46.8 \\
\hline 47 & 50 & 900 & & 430 & 32.9 & 59.0 \\
\hline 16 & 50 & 1090 & & 347 & 44.5 & 99.3 \\
\hline 46 & 50 & 1090 & & 351 & 35.5 & 98.4 \\
\hline 49 & 50 & 1090 & & 347 & 34.7 & 98.5 \\
\hline
\end{tabular}


Table V. Transverse DOP-26 iridium (blank identifications GR9-1 \#4; GR9-2 \#1, \#4, \#5, \#6, \#7) at different strain rates and temperatures (T): $0.2 \%$ yield stress (YS), ultimate tensile stress (UTS), fracture strain (elongation to fracture), and reduction in area (RA)

\begin{tabular}{ccccccc}
\hline \hline ID\# & Strain rate, $\mathrm{s}^{-1}$ & $\mathrm{~T},{ }^{\circ} \mathrm{C}$ & $\begin{array}{c}0.2 \% \mathrm{YS}, \\
\mathrm{MPa}\end{array}$ & $\begin{array}{c}\mathrm{UTS}, \\
\mathrm{MPa}\end{array}$ & $\begin{array}{c}\text { Fracture } \\
\text { strain, } \%\end{array}$ & RA, $\%$ \\
\hline $51 \mathrm{~T}$ & 0.001 & 750 & 92 & 361 & 33.1 & 79.7 \\
$52 \mathrm{~T}$ & 0.001 & 750 & 84 & 367 & 30.5 & 85.2 \\
$66 \mathrm{~T}$ & 0.001 & 750 & 75 & 357 & 30.5 & 86.1 \\
$53 \mathrm{~T}$ & 0.001 & 1090 & 68 & 229 & 35.4 & 94.8 \\
$54 \mathrm{~T}$ & 0.001 & 1090 & 67 & 232 & 35.1 & 98.8 \\
$68 \mathrm{~T}$ & 0.001 & 1090 & 70 & 231 & 35.8 & 96.1 \\
& & & & & & \\
$55 \mathrm{~T}$ & 10 & 750 & 92 & 503 & 32.7 & 44.9 \\
$62 \mathrm{~T}$ & 10 & 750 & 92 & 498 & 33.3 & 54.1 \\
$64 \mathrm{~T}$ & 10 & 750 & 95 & 485 & 35.0 & 48.2 \\
$58 \mathrm{~T}$ & 10 & 1090 & 83 & 333 & 35.8 & 99.1 \\
$65 \mathrm{~T}$ & 10 & 1090 & 89 & 329 & 29.8 & 100.0 \\
$67 \mathrm{~T}$ & 10 & 1090 & 80 & 337 & 36.1 & 97.2 \\
& & & & & & \\
$56 \mathrm{~T}$ & 50 & 750 & & 532 & 34.9 & 45.0 \\
$59 \mathrm{~T}$ & 50 & 750 & & 575 & 35.7 & 48.5 \\
$61 \mathrm{~T}$ & 50 & 750 & & 559 & 32.6 & 46.6 \\
$57 \mathrm{~T}$ & 50 & 1090 & & 348 & 40.0 & 98.8 \\
$60 \mathrm{~T}$ & 50 & 1090 & & 368 & 35.4 & 96.4 \\
$63 \mathrm{~T}$ & 50 & 1090 & & 362 & 38.1 & 99.8 \\
\hline \hline
\end{tabular}


Table VI. Averaged mechanical properties for longitudinal and transverse DOP-26 iridium alloy

\begin{tabular}{|c|c|c|c|c|c|c|c|c|c|}
\hline \hline $\begin{array}{c}\text { Strain } \\
\text { rate, } \mathrm{s}^{-1}\end{array}$ & $\mathrm{~T},{ }^{\circ} \mathrm{C}$ & $\begin{array}{c}\mathrm{YS}, \\
\mathrm{MPa}\end{array}$ & $\begin{array}{c}\mathrm{YS}, \\
\mathrm{MPa}\end{array}$ & $\begin{array}{c}\mathrm{UTS}, \\
\mathrm{MPa}\end{array}$ & $\begin{array}{c}\mathrm{UTS}, \\
\mathrm{MPa}\end{array}$ & $\begin{array}{c}\text { Fracture } \\
\text { strain, } \%\end{array}$ & $\begin{array}{c}\text { Fracture } \\
\text { strain, } \%\end{array}$ & RA, \% & RA, \% \\
\hline & & Long. & Trans. & Long. & Trans. & Long. & Trans. & Long. & Trans. \\
\hline $1 \times 10^{-3}$ & 25 & 124 & & 720 & & 9.4 & & 8.1 & \\
$1 \times 10^{-3}$ & 600 & 84 & & 438 & & 30.5 & & 54.4 & \\
$1 \times 10^{-3}$ & 750 & 80 & 84 & 342 & 362 & 32.7 & 31.4 & 93.7 & 83.7 \\
$1 \times 10^{-3}$ & 900 & 80 & & 282 & & 35.6 & & 94.0 & \\
$1 \times 10^{-3}$ & 1090 & 63 & 68 & 203 & 231 & 39.4 & 35.4 & 97.2 & 96.6 \\
& & & & & & & & & \\
10 & 25 & 134 & & 797 & & 10.4 & & 10.1 & \\
10 & 600 & 98 & & 589 & & 32.1 & & 40.8 & \\
10 & 750 & 95 & 93 & 489 & 495 & 32.8 & 33.7 & 54.4 & 49.1 \\
10 & 900 & 83 & & 396 & & 29.1 & & 58.9 & \\
10 & 1090 & 79 & 84 & 313 & 333 & 36.0 & 33.9 & 93.6 & 98.8 \\
& & & & & & & & & \\
50 & 25 & & & 770 & & 9.5 & & 9.0 & \\
50 & 600 & & & 654 & & 34.0 & & \\
50 & 750 & & & 536 & 555 & 37.2 & 34.4 & 50.0 & 46.7 \\
50 & 900 & & & 434 & & 32.7 & & 54.7 & \\
50 & 1090 & & & 348 & 359 & 38.2 & 37.8 & 98.7 & 98.3 \\
\hline \hline
\end{tabular}

Table VII. Heestand et al. tensile data [12] for stress-relieved $\left(1 \mathrm{~h} / 1025^{\circ} \mathrm{C}\right) \mathrm{DOP}-26$ iridium alloy (B2-7 sheet) tested at $925^{\circ} \mathrm{C}$ and $6.7 \times 10^{-1} \mathrm{~s}^{-1}$

\begin{tabular}{ccc}
\hline \hline Orientation & UTS, MPa & Elongation* \\
\hline longitudinal & 745 & 10.6 \\
longitudinal & 645 & 13.6 \\
transverse & 628 & 8.1 \\
Transverse & 692 & 9.6 \\
\hline \hline
\end{tabular}

*Ref. [12] does not provide details on the way in which the elongation to fracture was obtained. 


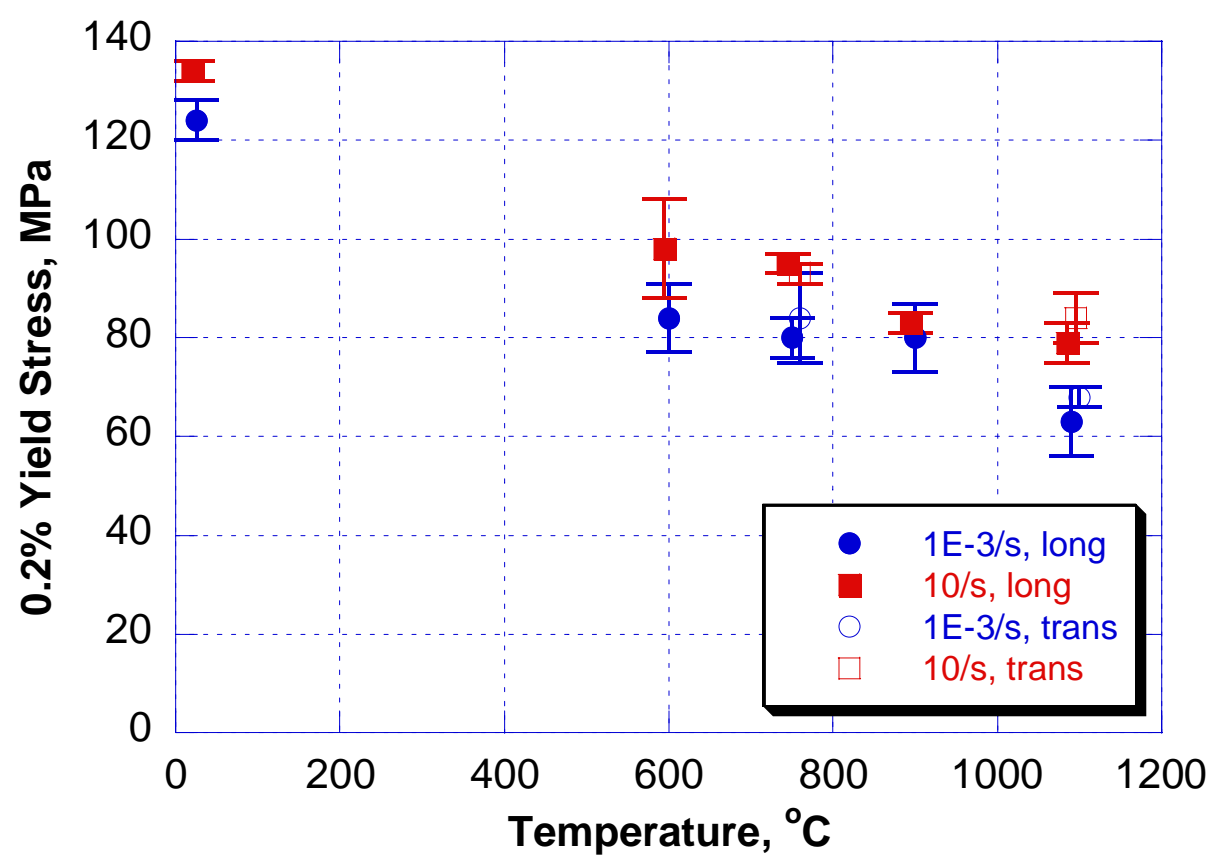

Fig. 24. Plot of yield stress vs. temperature for longitudinal and transverse orientations at different strain rates. The temperatures are shifted by small amounts in order to separate the standard deviation error bars.

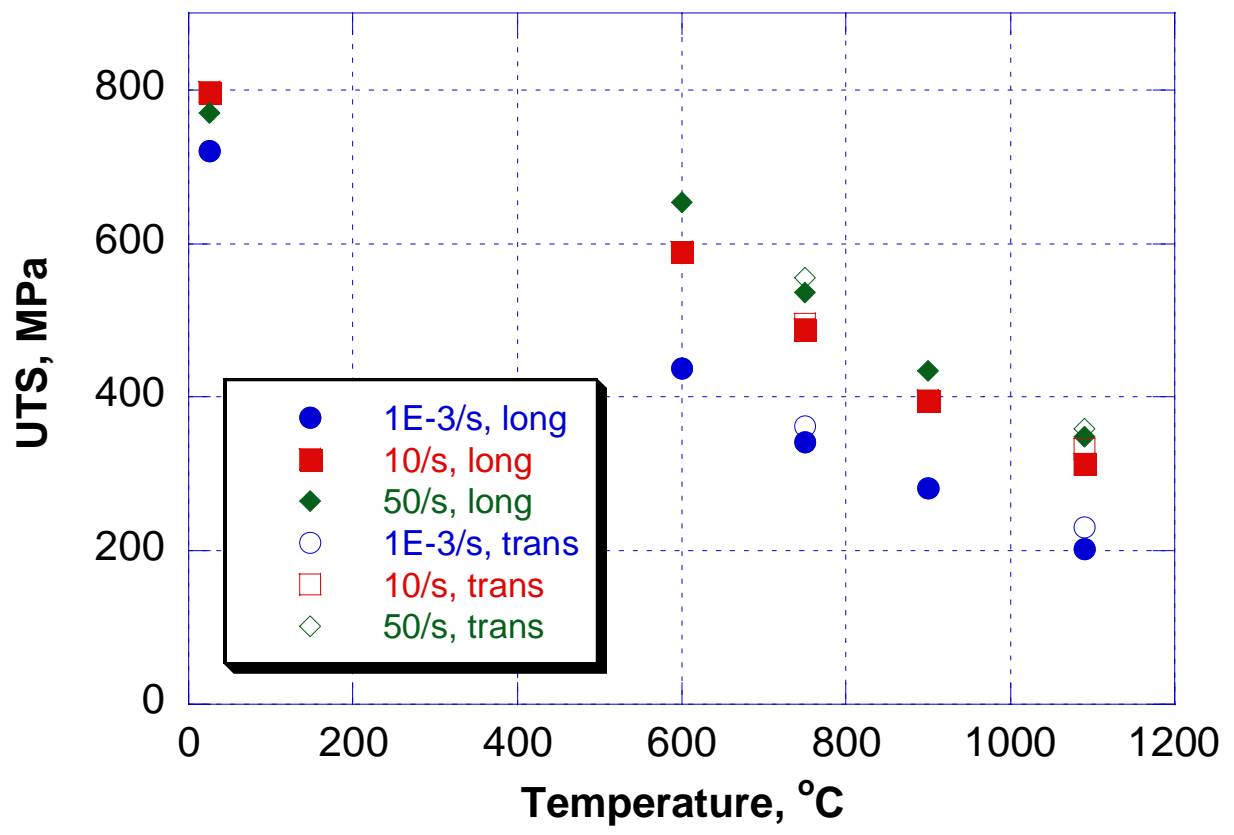

Fig. 25. Plot of ultimate tensile stress vs. temperature for longitudinal and transverse orientations at different strain rates. 


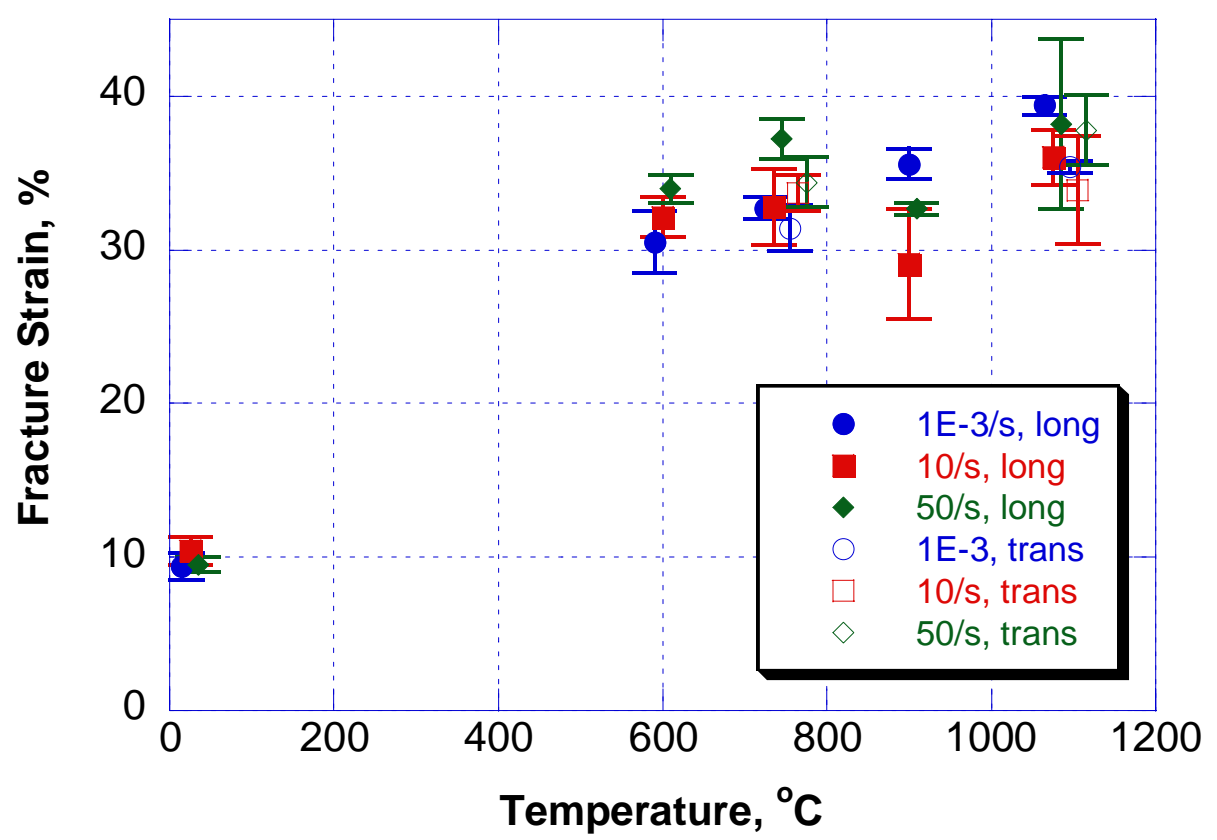

Fig. 26. Plot of fracture strain vs. temperature for longitudinal and transverse orientations at different strain rates. The temperatures are shifted by small amounts in order to separate the standard deviation error bars.

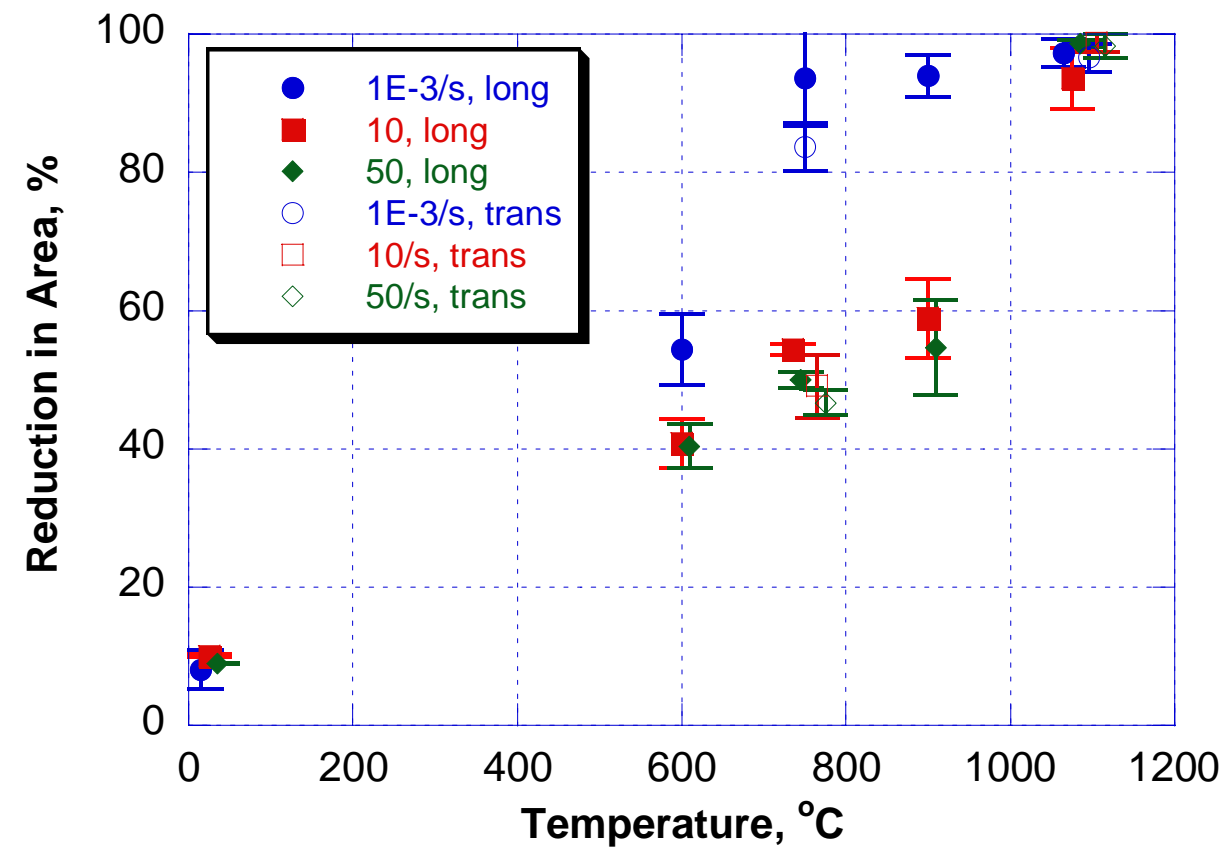

Fig. 27. Plot of reduction in area vs. temperature for longitudinal and transverse orientations at different strain rates. The temperatures are shifted by small amounts in order to separate the standard deviation error bars. 


\section{NON-UNIFORMITY OF DEFORMATION}

As long as adequate work-hardening occurs during a tensile test, the deformation in the gage section is uniform since the work-hardening counteracts the development of above-average local strains. At elevated temperatures, the work hardening rate decreases and non-uniform deformation is more likely to occur. Assuming that the mechanical properties in each specimen are homogeneous, any non-uniformity in the strain is due to non-uniformities in the gage cross section as well as temperature gradients along the gage. The exact specimen contours were not determined in this work, only the minimum and maximum widths in the center and the radii at the ends of the gage sections. Also, the temperature gradient was not measured rigorously - the only requirement was for the temperatures of the two thermocouples attached to the gage (with a separation about $5 \mathrm{~mm}$ ) not to differ by more than $20^{\circ} \mathrm{C}$. Tables VIII and IX tabulate the local strains evaluated from the spacing of adjacent indents for longitudinal and transverse specimens. Consistent with the high work hardening capacity, the strains in the gage sections are quite uniform at room temperature. At elevated temperatures, however, significant strain gradients develop because the work hardening rate is essentially zero for a large fraction of the test. This is illustrated in Figs. 28 and 29, which compare the local indent strains for the longitudinal specimens tested between 600 and $1090^{\circ} \mathrm{C}$ at strain rates of $1 \times 10^{-3}$ and $50 \mathrm{~s}^{-1}$, respectively. A comparison of the two figures shows clearly that the scatter is particularly high at the lower strain rate, for which the lowest amount of work hardening occurs. 
Table VIII. Local strains determined from the change in spacing of indents 1 through 7 for longitudinal DOP-26 specimens

\begin{tabular}{|c|c|c|c|c|c|c|c|c|c|}
\hline ID\# & $\begin{array}{c}\text { Strain } \\
\text { rate, } 1 / \mathrm{s}\end{array}$ & $\mathrm{T}, \mathrm{C}$ & $1-2, \%$ & $2-3, \%$ & $3-4, \%$ & $4-5, \%$ & $5-6, \%$ & $6-7, \%$ & $\begin{array}{c}\text { Indent } \\
\text { fracture } \\
\text { strain, \% }\end{array}$ \\
\hline 1 & $1 \times 10^{-3}$ & 25 & 8.8 & 8.4 & 8.7 & 8.5 & 8.7 & 8.6 & 8.6 \\
\hline 32 & $1 \times 10^{-3}$ & 25 & 8.5 & 8.9 & 8.9 & 9.7 & 8.7 & 8.8 & 9.0 \\
\hline 43 & $1 \times 10^{-3}$ & 25 & 9.2 & 10.6 & 10.8 & 9.8 & 9.9 & 9.9 & 10.0 \\
\hline 2 & $1 \times 10^{-3}$ & 600 & 44.4 & 56.2 & & 29.2 & 23.7 & 20.2 & 34.7 \\
\hline 19 & $1 \times 10^{-3}$ & 600 & & 36.6 & 28.9 & 23.6 & 21.2 & 18.5 & 25.8 \\
\hline 33 & $1 \times 10^{-3}$ & 600 & & 35.5 & 31.5 & 29.7 & 24.1 & 21.8 & 28.5 \\
\hline 20 & $1 \times 10^{-3}$ & 750 & 45 & & 39.5 & 27.3 & 23.7 & 18.9 & 30.8 \\
\hline 35 & $1 \times 10^{-3}$ & 750 & 29.9 & & 45.8 & 34 & 28.9 & 23.6 & 32.4 \\
\hline 4 & $1 \times 10^{-3}$ & 900 & & 46.1 & 39.2 & 30 & 27.5 & 24.4 & 33.5 \\
\hline 21 & $1 \times 10^{-3}$ & 900 & 53.4 & & 39.7 & 32.7 & 26 & 22.2 & 34.8 \\
\hline 36 & $1 \times 10^{-3}$ & 900 & & 51 & 38.1 & 39.6 & 38.2 & 26.9 & 38.8 \\
\hline 5 & $1 \times 10^{-3}$ & 1090 & 34.7 & 42.1 & & 44.8 & 40.1 & 34 & 39.1 \\
\hline 37 & $1 \times 10^{-3}$ & 1090 & & 58.2 & 46.9 & 34.2 & 28.4 & 23.3 & 38.2 \\
\hline 45 & $1 \times 10^{-3}$ & 1090 & 56.5 & & 48.4 & 35.7 & 34.6 & 28.6 & 40.8 \\
\hline 6 & 10 & 25 & 10.1 & & 10.2 & 10 & 9.9 & 10.1 & 10.1 \\
\hline 23 & 10 & 25 & 9.1 & 10.1 & 9.2 & 9.5 & 9.4 & 9.0 & 9.4 \\
\hline 38 & 10 & 25 & 11.1 & 11.1 & 12.9 & 11.1 & 11.3 & 10.6 & 11.4 \\
\hline 7 & 10 & 600 & 26.8 & 30.4 & 33.3 & 37.1 & 37.9 & & 33.1 \\
\hline 24 & 10 & 600 & 28.6 & 33.7 & 38.9 & & 34.6 & 26.9 & 32.5 \\
\hline 39 & 10 & 600 & 27.1 & & 43 & 40 & 34.3 & 28.8 & 34.6 \\
\hline 8 & 10 & 750 & 37.4 & 49.5 & & & 36.3 & 30.2 & 38.3 \\
\hline 25 & 10 & 750 & & 32.4 & 27.6 & 27.8 & 25.9 & 23 & 27.3 \\
\hline 40 & 10 & 750 & 35.5 & & 42.9 & 40.4 & 31.6 & 28.7 & 35.8 \\
\hline 9 & 10 & 900 & 29 & 32.8 & & 33.1 & 30.9 & 26.9 & 30.5 \\
\hline 26 & 10 & 900 & & 32.9 & 26.8 & 25.5 & 22.2 & 21.3 & 25.7 \\
\hline 41 & 10 & 900 & 35.4 & 47.6 & & 30.7 & 25.7 & 21.7 & 32.2 \\
\hline 11 & 10 & 1090 & 21.8 & 29.1 & 36.5 & 41 & 48.3 & & 35.4 \\
\hline 27 & 10 & 1090 & 36.8 & 45.8 & 41.7 & & 43.5 & 32.5 & 40.1 \\
\hline 42 & 10 & 1090 & 36.8 & & 60.8 & 32.2 & 26 & 21.4 & 35.5 \\
\hline 12 & 50 & 25 & 9.6 & & 9.4 & 9.9 & 9.4 & 9.1 & 9.5 \\
\hline 28 & 50 & 25 & 10 & 10.6 & 10.2 & 10.4 & 10.5 & 10.3 & 10.3 \\
\hline 44 & 50 & 25 & 9.5 & 9.4 & 9.7 & 9.0 & 8.7 & 9.9 & 9.4 \\
\hline 13 & 50 & 600 & 26.9 & 31.2 & 36.3 & 39.2 & & & 33.4 \\
\hline 29 & 50 & 600 & 31.2 & 37.9 & & 38.2 & 29.7 & 28.6 & 33.1 \\
\hline 50 & 50 & 600 & 32.6 & & 41.6 & 35.8 & 32.2 & 30.4 & 34.5 \\
\hline 14 & 50 & 750 & 30.6 & 33.9 & 43.5 & 39.3 & 43.6 & & 38.2 \\
\hline 17 & 50 & 750 & 28.5 & 31.1 & 32.3 & 31.2 & & 37.5 & 32.1 \\
\hline 48 & 50 & 750 & 34.3 & 39.4 & 49 & & 38.4 & 31.8 & 38.6 \\
\hline 15 & 50 & 900 & 25.4 & 28.3 & 30.5 & & & 37.8 & 30.5 \\
\hline 30 & 50 & 900 & 33.9 & & & 41.8 & 34.3 & 27.7 & 34.4 \\
\hline 47 & 50 & 900 & 35.6 & 42.5 & & 34.2 & 29.9 & 25.7 & 33.6 \\
\hline 16 & 50 & 1090 & 51.6 & & & 56.2 & 41.4 & 35.3 & 46.1 \\
\hline 46 & 50 & 1090 & 32.8 & 37.9 & 40.1 & & & 28.5 & 34.8 \\
\hline 49 & 50 & 1090 & 32.3 & & & 36.9 & 29.5 & 25.8 & 31.1 \\
\hline
\end{tabular}


Table IX. Local strains determined from the change in spacing of indents 1 through 7 for transverse DOP-26 specimens

\begin{tabular}{|c|c|c|c|c|c|c|c|c|c|}
\hline ID\# & $\begin{array}{c}\text { Strain } \\
\text { rate, } \mathbf{s}^{-1}\end{array}$ & $\mathrm{~T}, \mathrm{C}$ & $1-2, \%$ & $2-3, \%$ & $3-4, \%$ & $4-5, \%$ & $5-6, \%$ & $6-7, \%$ & $\begin{array}{c}\begin{array}{c}\text { Indent } \\
\text { fracture } \\
\text { strain, \% }\end{array} \\
\end{array}$ \\
\hline $51 \mathrm{~T}$ & $1 \times 10^{-3}$ & 750 & 21.2 & 24 & 32.9 & 39.9 & 49.2 & & 33.4 \\
\hline $52 \mathrm{~T}$ & $1 \times 10^{-3}$ & 750 & 24.6 & 27.3 & 26.8 & 31 & 37.8 & & 29.5 \\
\hline $66 \mathrm{~T}$ & $1 \times 10^{-3}$ & 750 & 20.9 & 23.2 & 26.3 & 30.4 & 35.9 & & 27.3 \\
\hline $53 \mathrm{~T}$ & $1 \times 10^{-3}$ & 1090 & 24.4 & 27.5 & 34 & & 46.6 & 49.1 & 36.3 \\
\hline $54 \mathrm{~T}$ & $1 \times 10^{-3}$ & 1090 & 28 & 30.1 & 30.7 & 31.6 & & & 30.1 \\
\hline $68 \mathrm{~T}$ & $1 \times 10^{-3}$ & 1090 & 20.3 & 29.4 & 32.3 & 40.4 & 39.9 & 50.4 & 35.5 \\
\hline $55 \mathrm{~T}$ & 10 & 750 & 26.3 & 29.1 & 33.4 & 36 & & 31.2 & 31.2 \\
\hline $62 \mathrm{~T}$ & 10 & 750 & 26.4 & 35.5 & 40.1 & 38.9 & 39.1 & & 36.0 \\
\hline $64 \mathrm{~T}$ & 10 & 750 & 29 & 33.4 & 38.3 & & 37 & 31.4 & 33.8 \\
\hline $58 \mathrm{~T}$ & 10 & 1090 & 26.4 & 30.7 & 39.3 & 51.1 & & 43.8 & 38.3 \\
\hline $65 \mathrm{~T}$ & 10 & 1090 & 21.5 & 27.4 & 26.7 & 28.2 & 33.2 & & 27.4 \\
\hline $67 \mathrm{~T}$ & 10 & 1090 & 31.6 & 39.9 & & 42.1 & 43.4 & 36.2 & 38.6 \\
\hline $56 \mathrm{~T}$ & 50 & 750 & 32.5 & 33 & 31.5 & 36 & 44.6 & & 35.5 \\
\hline $59 \mathrm{~T}$ & 50 & 750 & 28.4 & 30.5 & 36.8 & 51.8 & & 43 & 38.1 \\
\hline $61 \mathrm{~T}$ & 50 & 750 & 25.6 & 30.5 & 33.4 & 35.9 & 41.5 & & 33.4 \\
\hline $57 \mathrm{~T}$ & 50 & 1090 & 34.8 & & 42.3 & 37.9 & 39.9 & 50.7 & 41.1 \\
\hline $60 \mathrm{~T}$ & 50 & 1090 & 24.4 & 29.1 & 38.4 & 40.5 & 39.5 & & 34.4 \\
\hline $63 \mathrm{~T}$ & 50 & 1090 & 24.6 & 30.9 & 38.2 & & 43.7 & 61.1 & 39.7 \\
\hline
\end{tabular}




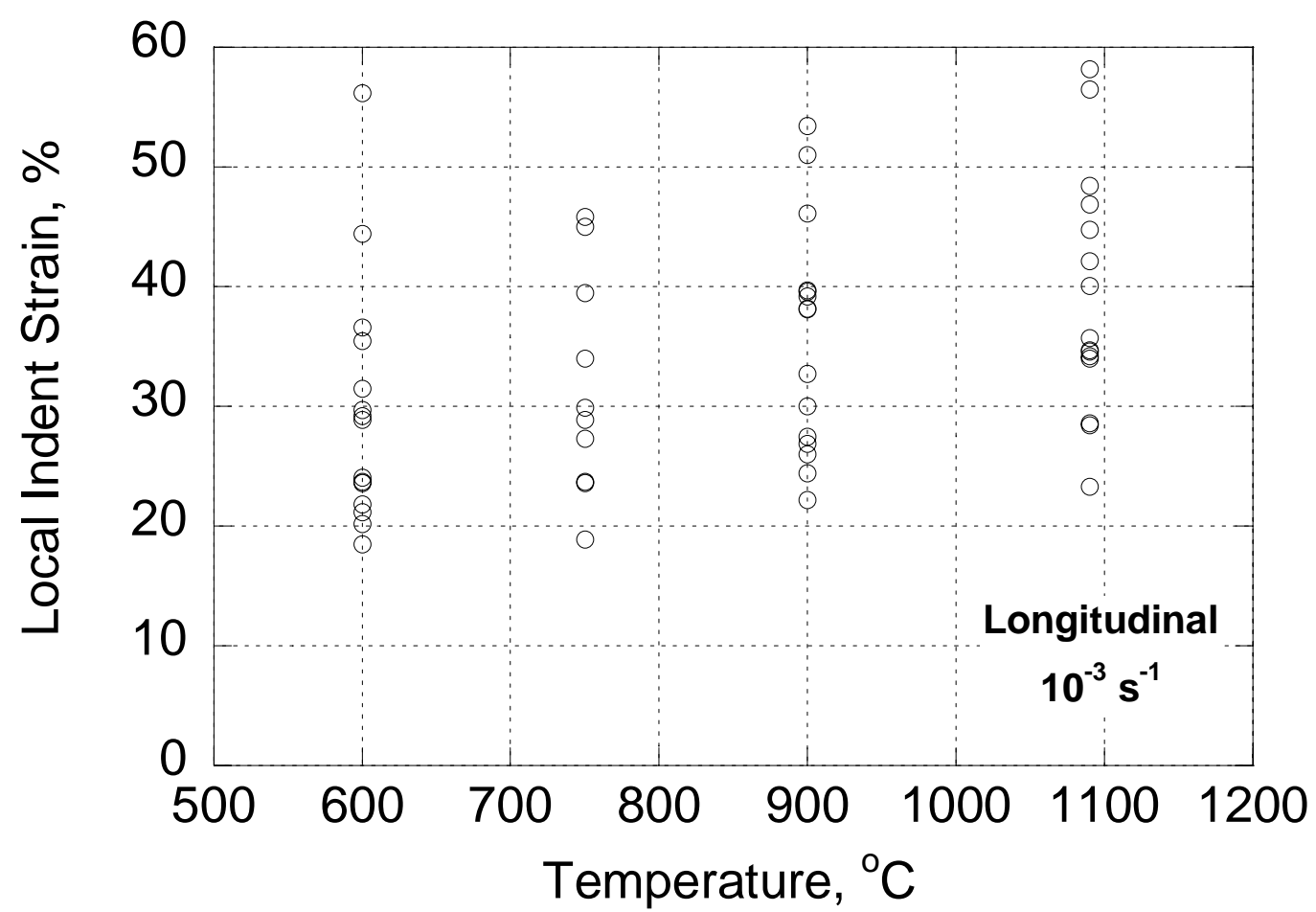

Fig. 28. Local indent fracture strains for longitudinal DOP-26 specimens tested at $1 \times 10^{-3} \mathrm{~s}^{-1}$.

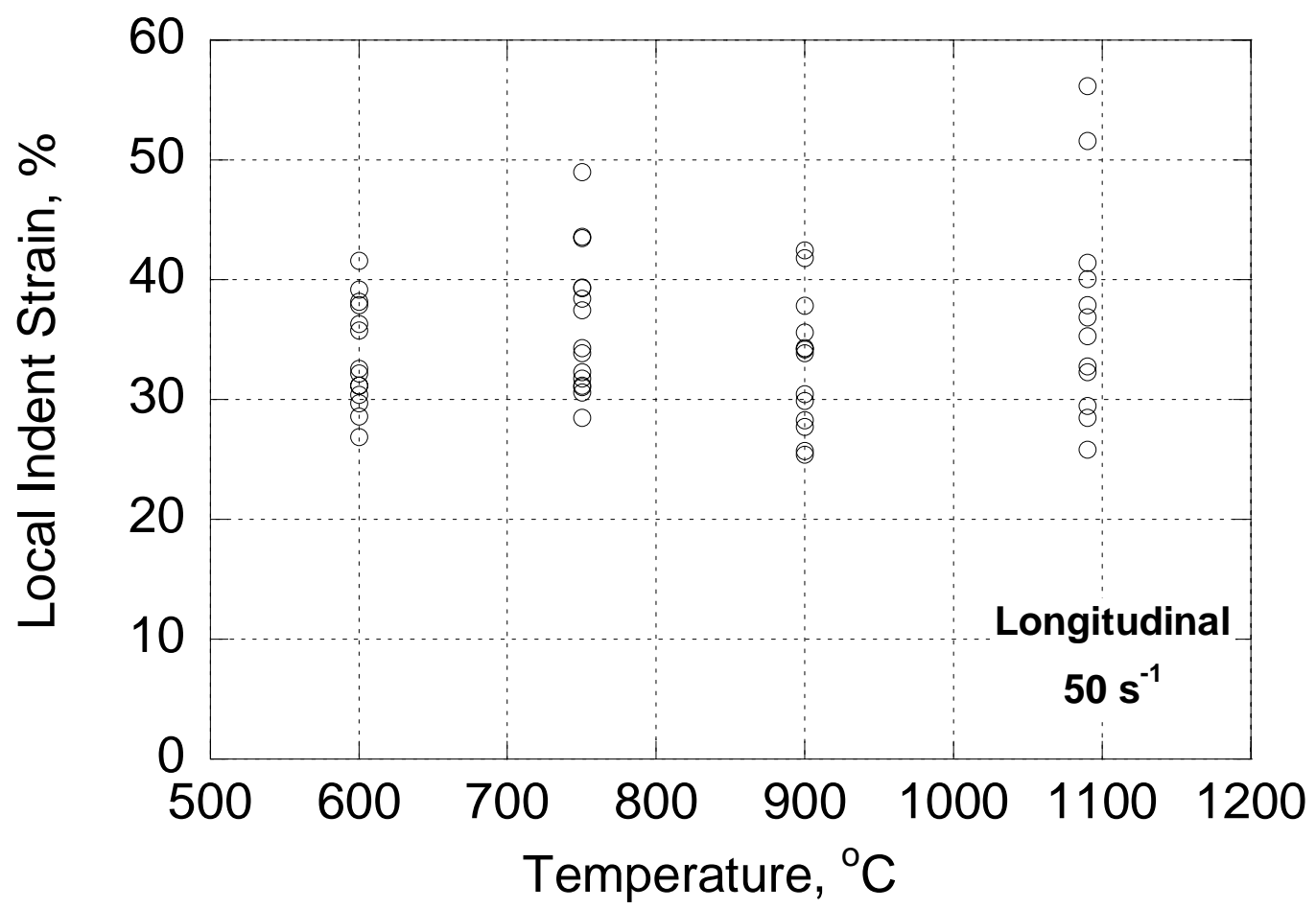

Fig. 29. Local indent fracture strains for longitudinal DOP-26 specimens tested at $50 \mathrm{~s}^{-1}$. 


\section{SUGGESTIONS FOR FURTHER WORK}

While the mechanical property data obtained in this work adds to the data base for DOP-26, further improvements in the testing procedure as well as tests at significantly higher strain rates are desirable. A list of suggestions for further work follows:

1. Proof-of-principle tests should be performed to determine whether a flat area of contact between the specimen and grip will minimize the plastic deformation observed in the head section at stresses below the macroscopic yield stress.

2. At strain rates above $10 \mathrm{~s}^{-1}$, data acquisition rates much higher than the $5 \mathrm{kHz}$ used in the present work are required.

3. In order to minimize the temperature gradients along the gage length it would be desirable to permanently attach at least three thermocouples to a Pt strip, with the spacing of the two outer thermocouples being $10 \mathrm{~mm}$. The Pt strip instrumented in this way should then be wirewrapped to the gage length of the specimens. With three or more thermocouples it will be easier to minimize any temperature gradients by the susceptor design and position.

4. The measurements of the indent fracture strains show significant scatter from specimen to specimen. If the number of indents would be increased above the present value of 7 , the accuracy of the strain measurements would be improved. It may also be worth considering other ways of strain measurement. For example, modern inspection equipment makes it easy to automatically measure the detailed shape of a specimen before and after testing in order to calculate the local strains at very small intervals along the gage length.

5. The maximum strain rate employed in the present work, $50 \mathrm{~s}^{-1}$, may not be fast enough to convincingly demonstrate the effect of strain rate on ductility and testing direction (transverse vs. longitudinal). However, at a strain rate of $50 \mathrm{~s}^{-1}$ ringing of the load cell does already become a problem. Extending the experiments to strain rates of 500 or $1000 \mathrm{~s}^{-1}$ at elevated temperatures will likely involve a significant research effort. 


\section{SUMMARY AND CONCLUSIONS}

DOP-26 specimens in the recrystallized condition (vacuum anneal of 1 hour at $1375^{\circ} \mathrm{C}$ ) were tested in tension in orientations parallel and perpendicular to the rolling direction of the sheet from which they were fabricated. The tests were performed at temperatures ranging from room temperature to $1090^{\circ} \mathrm{C}$ and strain rates ranging from $1 \times 10^{-3}$ to $50 \mathrm{~s}^{-1}$. Room temperature testing was performed in air, while testing at elevated temperatures was performed in a vacuum better than $1 \times 10^{-4}$ Torr. The yield stress (YS) and the ultimate tensile stress (UTS) values decreased with increasing temperature and decreasing strain rate. Between 600 and $1090^{\circ} \mathrm{C}$, the ductility (elongation to fracture) showed a slight increase with increasing temperature, whereas, within the scatter of the data, the ductility did not depend on the strain rate. The reduction in area (RA), on the other hand, decreased with increasing strain rate. The YS and UTS values did not differ significantly for the longitudinal and transverse specimens. The ductility and RA values of the transverse specimens were marginally lower than those of the longitudinal specimens.

While the results of this report add significantly to the data base on the mechanical properties of DOP-26, it would be desirable to improve and extend the data. An improved specimen-grip design to minimize plastic deformation during seating of the specimens prior to yielding, improved control of temperature gradients along the gage length, and increased data collection rates are desirable. Strain rates between 50 to $5000 \mathrm{~s}^{-1}$ need to be examined in order to fully characterize the strain rate sensitivity of the mechanical properties of DOP-26. Such tests will require special precautions in order to minimize ringing of the load cell, and their successful implementation will likely require a significant research effort. 


\section{REFERENCES}

1. E. P. George and C. T. Liu, Micro- and Macro-Alloying of Ir-Base Alloys, in Iridium (eds. E. K. Ohriner, R. D. Lanam, P. Panfilov, and H. Harada), The Minerals, Metals and Materials Society, Warrendale, PA, 2000, pp. 3-14.

2. C. T. Liu and H. Inouye, Study of Iridium and Iridium-Tungsten Alloys for Space Radioisotopic Heat Sources, Report ORNL-5240, Oak Ridge National Laboratory, Oak Ridge, Tennessee, December 1976.

3. C. T. Liu and H. Inouye, Development and Characterization of an Improved Ir-0.3\% W Alloy for Space Radioisotopic Heat Sources, Report ORNL-5290, Oak Ridge National Laboratory, Oak Ridge, Tennessee, October 1977.

4. C. T. Liu, H. Inouye, and A. C. Schaffhauser, Metallurgical and Mechanical Properties of Thorium-Doped Ir-0.3\% W Alloys, Report ORNL-5616, Oak Ridge National Laboratory, Oak Ridge, Tennessee, April 1980.

5. C. T. Liu, H. Inouye, and A. C. Schaffhauser, Metall. Trans. A, 12A (1981) 9931002.

6. H. Inouye and C. T. Liu, Iridium-Hafnium Alloy, U.S. Patent 3,918,965, November 11, 1975.

7. C. L. White, R. E. Clausing, and L. Heatherly, Metall. Trans. A, 10A (1979) 683-691.

8. T. G. George and M. F. Stevens, JOM, 40 (Oct 1988) 32-35.

9. A. N. Gubbi, E. P. George, E. K. Ohriner, and R. H. Zee, Metall. Mater. Trans. A, 28A (1997) 2049-2057.

10. E. P. George, C. G. McKamey, E. K. Ohriner, and E. H. Lee, Mater. Sci. Eng. A319-321 (2001) 466-470.

11. G. B. Ulrich, Heat-Resistant Materials, edited by K. Natesan and D. J. Tillack, ASM International, Materials Park, Ohio, 1991, pp. 187-195.

12. R. L. Heestand, E. K. Ohriner, and T. K. Roche, Advances in Iridium Alloy Processing in 1987, Report ORNL/TM-10852, Oak Ridge National Laboratory, August 1988. 


\section{INTERNAL DISTRIBUTION}

1. C. A. Carmichael

2. E. P. George

3-4. J. F. King

5. E. K. Ohriner

6. R. G. Miller
7-9. J. H. Schneibel

10. G. B. Ulrich

11. S. J. Zinkle

12. ORNL Technical Information Office (RC)

\section{EXTERNAL DISTRIBUTION}

13. Robert T. Carpenter, Orbital Sciences Corporation 20030 Century Blvd., Suite 102, Germantown, MD 20874

14. John Dowicki, Office of Radioisotope Power Systems, NE-34/GTN, U. S. Department of Energy, 1000 Independence Avenue SW, Washington, DC 205851290

15. Stephen G. Johnson, Idaho National Laboratory, P. O. Box 1622, MS-6122, Idaho Falls, ID 83415

16. Office of Scientific and Technical Information (PDF file to ORNL Releasing Official, R. P. Migun)

17. Emil Skraek, Orbital Sciences Corporation, 2003 Century Blvd., Suite 102, Germantown, MD 20874

18. Craig E. Van Pelt, Los Alamos National Laboratory, P. O. Box 1633, Los Alamos, NM 87545

19. Robert L. Wiley, Office of Radioisotope Power Systems, NE-34/GTN, U. S.

Department of Energy, 1000 Independence Avenue SW, Washington, DC 205851290 